\title{
Copper for the Pharaoh: identifying multiple metal sources for Ramesses' workshops from bronze and crucible remains
}

Frederik W. Rademakers ${ }^{1}$, Thilo Rehren ${ }^{1,2}$ and Ernst Pernicka ${ }^{3}$

\section{Abstract}

The origin of copper used in Late Bronze Age (LBA) Egypt is very poorly understood despite its cultural and economic importance attested in archaeological and historical sources. Extensive literature discusses major LBA copper sources such as Cyprus (oxhide ingots), Oman (bun ingots) and Egyptian-controlled sites in the Sinai. This paper presents new chemical and lead isotope data for Egyptian copper alloys excavated in several bronze production workshops from the New Kingdom capital Pi-Ramesse, expanding on earlier data from Amarna. Supporting data is obtained from the analysis of crucible remains from the same context, for which the potential contribution of lead isotope analysis is critically evaluated.

Diachronic changes in the provisioning of these Egyptian workshops are discussed, incorporating an extensive overview of currently known Egyptian mining and metallurgy. The results have major implications for our understanding of LBA copper circulation in the wider region, for the first time analysing a major Egyptian 'consumer' assemblage.

The analytical results reveal a complex picture of variable copper supply to the Ramesside workshops, which involved both the recycling of existing bronzes and the use of freshly smelted copper from various origins to produce fresh alloys. Importantly, this includes crucial new evidence for the melting of (Cypriot) oxhide ingot fragments in crucibles for alloying.

The royal, internationally connected nature of these workshops makes Pi-Ramesse an exceptional case study of LBA metal trade, and hypotheses raised in this paper highlight the urgent need for more extensive analysis of ancient Egyptian copper artefacts to grasp metal circulation throughout Egypt's long history. More refined frameworks, incorporating the variety of private as well as royal contexts, will improve understanding of Egypt's ancient economic organisation. This paper offers new perspectives onto LBA metal supply and consumption networks, with broader archaeological interpretative models of economic and political interactions across the wider ancient Near East.

Keywords: Late Bronze Age, Egypt, bronze, crucibles, lead isotopes, chemical analysis

${ }^{1}$ UCL Institute of Archaeology, London, $U K^{1}$

+447598915857

frederik.rademakers@gmail.com

${ }^{2}$ College of Humanities and Social Sciences, HBKU, Doha, Qatar

+974 77770275

\footnotetext{
${ }^{1}$ Present address:

KU Leuven, Division of Geology, Leuven, Belgium

+3216374545

frederik.rademakers@kuleuven.be
} 
th.rehren@ucl.ac.uk

${ }^{3}$ Curt-Engelhorn-Zentrum Archäometrie gGmbH an der Universität Heidelberg, Mannheim, Germany

+496212938946

ernst.pernicka@cez-archaeometrie.de 


\section{Highlights}

- Both freshly-smelted copper and bronze scrap used in workshops

- Arabah, Cypriot and probably Omani and Sinai copper in Pi-Ramesse

- First securely attested melting of oxhide ingot: implication for provenance studies

- New model outlined for copper circulation in New Kingdom Egypt

- Method development for LI analysis of bronze crucibles 


\section{1 - Introduction}

The archaeological remains of Pi-Ramesse (Pusch and Herold, 1999) in the eastern Nile Delta (Figure 1), established as the Egyptian capital under Ramesses II, have been excavated from 1980 onwards by the Roemer-Pelizaeus Museum (Germany) by Dr Pusch and his team, and continue today under the direction of Dr Franzmeier at UCL Qatar. The ancient bronze workshops in Pi-Ramesse, active during the $13^{\text {th }}$ century BCE, revealed one of the largest assemblages of bronze production waste currently known from the Late Bronze Age (LBA) Mediterranean region. Major metallurgical activities were attested in excavation area QI (Figure 2), with a smaller workshop excavated in area QIV. Strong indications exist, however, that the actual bronze workshop area extended over a much larger area, amidst other hightemperature activities (glass, faience and Egyptian blue production) to which copper was crucial (Rehren, et al., 2001).

The first phase of activity (phase $\mathrm{B} / 3$, see Table 1 ) is primarily attested in the northern part of area QI: here, large-scale melting and alloying of large amounts of bronze took place in an industrial-style group of melting batteries that could be operated simultaneously (Pusch, 1990, 1994). Two major operations are attested by the changing orientation (W-E to N-S) of the melting batteries and associated cross-furnaces in phases $\mathrm{B} / 3 \mathrm{~b}$ and $\mathrm{B} / 3 \mathrm{a}$. This industrial area probably covered at least $10,000 \mathrm{~m}^{2}$ (dashed red line in Figure 2), as shown by soundings (Rehren et al., 1998) and earlier excavations (Hamza, 1930). South of the wall delimiting this industrial area more limited bronze production evidence was discovered in several smaller multi-functional workshops (Prell, 2011), which employed the same crucibles in more ephemeral melting hearths. During the second phase of activity (phase B/2), the large industrial area was shut down and converted into a training courtyard for chariots, while the multifunctional workshops (southern QI area) expanded their activities (probably in support of the chariot army). The QIV evidence, which appears to belong to a distinct metals workshop, similarly dates to phase $\mathrm{B} / 2$.

Dating of these phases (Table 1) is constrained by pottery, architectural inscriptions and other finds, as discussed by Pusch (1990, 2000), placing stratum B/2 in the mid-reign of Ramesses II (ca. $1250 \mathrm{BC}$ ), and stratum B/3 during his early reign or before. Details of excavation methods and a full overview of find densities in the different workshop areas is provided by Pusch (1990) and Prell (2011). 
The same crucibles were employed throughout these workshops and phases, and used for the melting of recycled bronze, as well as the alloying of fresh (raw) copper with cassiterite and probably tin, as shown by analysis of mounted crucible sections (Rademakers et al., in press).

This paper further investigates the copper available within these different workshops, through the combination of results from chemical and lead isotope analysis of various metal artefacts. The aim is to assess variability between these different workshops through time, and to tentatively suggest possible sources of copper at hand in Pi-Ramesse. This ties in with the technological narrative for Pi-Ramesse, but furthermore greatly expands the currently available database for copper circulating in ancient Egypt, which is poorly represented in the (lead isotope) literature.

While this paper investigates the nature and possible provenance of metals, this must be understood within the particular context of large-scale bronze workshops, rather than the more prevalent discussion of individual objects' provenance. As such, an attempt is made to reconstruct the flow of various copper batches through these workshops. In this respect, crucibles used for the melting and alloying of bronze offer a proxy for the passage of metal on an archaeological site that may otherwise be lacking in metal finds. They are indicative of copper or bronze arriving to a workshop as either fresh metal or scrap, to be molten down and cast into new shapes. While cast metal objects may move over large distances subsequently, crucibles tend to remain in place after use and can provide a steady waypoint in the life journey of a metal. By integrating the results of this paper with those of crucible slag analysis, a holistic interpretation of bronze casting technology is intended here. 


\section{2 - Materials and methods}

26 copper alloys, including casting waste, metal prills and (broken) artefacts, have been analysed for their chemical and lead isotope (LI) composition. These were selected to obtain a representative spread across contexts and time, taking into account considerations of object size, corrosion, and, most decisively, sample availability and budget considerations. As such, they are far from an ideal statistical sample, but offer a qualitative assessment of compositional variability within the Pi-Ramesse bronzes. These samples and their contextual data are presented in Table 2, where PQ (Planquadrate) refers to the excavation squares ax-f/03-6 shown in Figure 2. These include 17 (partly corroded) casting spills, 7 objects and 2 metal prills extracted from crucibles. Objects for which drawings were available (20 out of 26) are shown in Figure 3. For the objects, small samples $(<0.1 \mathrm{~g})$ were taken by either clipping (steel pincer) or drilling (steel drill), and corrosion layers mechanically removed prior to analysis. Many casting waste samples were, however, internally corroded (cuprite) to some degree (postsampling) and their chemical composition should be considered approximate (cfr. Table 2).

The results for the LI analysis of all copper (alloys) are shown in Figure 4. Nine metal samples were analysed by the Oxford Isotrace Laboratory (using TIMS: Thermal Ionisation Mass Spectrometry; following the protocol outlined by Stos-Gale et al. (1995b)) in 1996 within the Pi-Ramesse project but have hitherto not been published, with the exception of an oxhide ingot fragment (Stos-Gale, 2011). The majority of the data has been produced within the framework of the first author's PhD by the Curt-Engelhorn-Centre for Archaeometry (CEZA) (17 samples) using MC-ICP-MS (Multi-Collector Inductively Coupled Plasma Mass Spectrometry - type Neptune plus), following the protocol detailed by Niederschlag et al. (2003). Lab-XRF (X-ray Fluorescence) analysis was performed for all metal samples (Isotrace and CEZA (Lutz and Pernicka, 1996)), and NAA (Neutron Activation Analysis (Pernicka, 1984)) for 7 of the metal samples (CEZA), summarised in Tables 3 and 4. The LI ratios are presented in the familiar ${ }^{207} \mathrm{~Pb} /{ }^{206} \mathrm{~Pb}-{ }^{208} \mathrm{~Pb} /{ }^{206} \mathrm{~Pb}$ space, as well as the less common ${ }^{206} \mathrm{~Pb} /{ }^{204} \mathrm{~Pb}-{ }^{207} \mathrm{~Pb} /{ }^{204} \mathrm{~Pb}$ space frequently used in geochemistry, which provides a better means to distinguish between some lead sources (Baron et al., 2014; Höppner et al., 2005; Pernicka et al., 1993). These results are discussed in section 3.

13 crucibles (12 ceramic and 13 slag samples) from the same workshop contexts, previously analysed in mounted section, were equally analysed for their LI ratios by the CEZA. Crucible slag is defined here as the layer that has developed at the interface of the crucible and its charge, 
through the combination of vitrified ceramic and various contributions from the crucible charge, such as fuel ash and metal (oxides). The samples were taken from the same crucible fragments previously sampled for analysis in mounted section, physically separating ceramic and slag parts (crucibles and their ceramic/slag zoning illustrated by Rademakers and Rehren (2016), Rademakers et al. (in press)). An attempt has been made to reflect here the different groups discovered through crucible slag analysis (optical microscopy and SEM-EDS analysis): 'clean', iron contaminated, iron-cobalt contaminated and (mildly) lead contaminated crucibles (full results of mounted section analysis mentioned in this paper: Rademakers, 2015; Rademakers et al., in press). Sample availability and budget considerations again dictate sample numbers, which offer a qualitative insight into the LI variability within the Pi-Ramesse crucibles, rather than a statistically representative sample. Technological and chemical variability of the actual crucibles has been described using a satisfactorily large sample. LI ratios of the samples, with contextual information, are presented in Table 5, which further indicates the enrichment of crucible slag in copper contaminants as previously noted in mounted section analysis. Table 6 presents the results of chemical analysis by NAA and QICPMS (Quadrupole Inductively-Coupled Plasma Mass Spectrometry of samples dissolved in mineral acids) of crucible slag. These data do not represent bulk chemistry, which is dominated by $\mathrm{SiO}_{2}, \mathrm{Al}_{2} \mathrm{O}_{3}, \mathrm{FeO}$ and $\mathrm{CaO}$ (80-90 wt\%: SEM-EDS), but rather ceramic and slag contaminants. This trace element data is most useful for metallurgical issues (though not in a straightforward way, cfr. section 4), while bulk chemical and micrograph data are mainly useful for technological reconstructions of crucible technology. The latter can, however, provide important complementary provenance indicators. 


\section{3 - Results: metals}

Lead contents vary between $<0.01$ to $1.1 \%$ (average: ca. $0.5 \%$, all percentage values are given as mass percent), with the exception of three samples with ca. $2 \%$, and one with ca. $5 \% \mathrm{~Pb}$. Eight samples, indicated in Figure 4, have very low lead contents. LI ratios show a fairly wide spread, pointing to copper from various geological sources being used. No radiogenic lead appears to be present in any of the samples. Rather than discussing the complete dataset straight away, the following sections are organised by groupings in the assemblage apparent from typology, (trace) chemistry and LI ratios. Conformity (chemical and LI ratios) to known copper ore sources and other ancient metal assemblages is assessed in the first instance, but this is not immediately assumed to verify a direct link where correspondence is noted. Rather, a combination of LI (in)consistency, chemical (dis)similarity and artefact attributes are used to narrow down the list of possible explanations for the origins of copper in Pi-Ramesse. This is done within the methodological boundaries of LI analysis (undistinguishable ore sources, possible existence of hitherto undiscovered/uncharacterised copper ore deposits exploited in antiquity, distorting effects from ancient copper recycling and particularly mixing), and trace element chemistry (presence/absence considered more informative than absolute contents) with respect to provenance studies (Pernicka, 2014). From the resulting overview, the most likely explanations are elaborated here. A tentative overall interpretation of the data, integrating crucible analysis results (section 4), is discussed in section 5.

\subsection{Cyprus}

The oxhide ingot fragment has previously been identified as matching with the LI characteristic of copper ores from Cyprus (in particular the Apliki ore body: Gale, 1999; Stos-Gale, 2011). Figure 5 shows a comparison between the LI composition of the copper (alloy) samples from Pi-Ramesse, Cypriot copper ores (data from Gale et al., 1997) from the Solea axis (the geological structure encompassing the Apliki ore body; see Constantinou, 1980), and copper ingots from the Uluburun wreck (ingot core data from Gale, 2005). The oxhide ingot fragment indeed matches these Cypriot ores, as well as oxhide ingots from the Uluburun wreck and certain Levantine ingots (Yahalom-Mack et al., 2014; not shown) previously identified as Apliki-consistent. Furthermore, the two metal prills which were extracted from Pi-Ramesse crucible slag for analysis lie very close to the oxhide ingot and match the Cypriot Apliki ores as well. Their chemical composition (Table 3) is similarly consistent with a Cypriot origin 
(trace element data of oxhide ingots isotopically matching the Solea axis: Gale, 1999; Hauptmann et al., 2002; Primas and Pernicka 1998), including the remarkably low lead contents characteristic of Apliki copper (Kassianidou, 2009). Variable iron content (0-1.6\%) could point to the variable degree of refining, and resulting presence/absence of iron-rich (sulphide) inclusions (Hauptmann et al., 2002) in different ingots, within a single ingot (fragment) or even within a single crucible process (Rademakers and Rehren, 2016). The prills' low tin concentrations are most likely due to minor contamination in the crucible. This result is particularly interesting, as it demonstrates the melting of an LBA oxhide ingot (fragment) in a crucible for the first time. However, it also shows that some kind of mixing, in this case probably unintentionally, has occurred.

Close resemblance exists between two samples (1986_0720 and 1992_0905) and copper ores from the Limassol forest (data from Gale et al., 1997; not shown). However, exploitation of this copper source during the LBA is unclear (Kassianidou, 2013) and is mainly confined to Hellenistic and Roman times (Constantinou, 1980; Hauptmann, 2007; Stos-Gale et al., 1997). These two samples' provenance is better explained differently below.

\subsection{Moderately lead-rich samples - Faynan/Timna}

Figure 5 shows a comparison of the LI composition of the Pi-Ramesse metal samples with Faynan (data from Hauptmann et al., 1992, 2015) and Timna (data from Gale et al., 1990) copper ores. The three samples with ca. 1.7-2\% lead all fall within the LI range characteristic for both Faynan DLS (Dolomite Limestone Shale unit) and Timna ores, which are geologically very similar. Their moderate lead content is in line with an interpretation as (raw) copper smelted from either, though lead contents for Timna tend to be lower (Hauptmann, 2007). Interestingly, these three samples all belong to the QIV context.

It must be noted that major mining and smelting activities for both Faynan and Timna should be situated in the Iron Age rather than the LBA (Hauptmann, 2007; Rothenberg, 1980), as verified by recent excavations (Ben-Yosef et al., 2010, 2012; Levy et al., 2012). Lower but significant activity did, however, already take place during the LBA. Given strong indications for cultural contact between Egypt and Timna during the LBA (Rothenberg, 1987, 1988, 1990) and its geographical vicinity, it may seem likely that these three samples represent Timna copper, for which similar lead contents sometimes occur (Rothenberg, 1990: Table 6, p. 70). Faynan, however, cannot be excluded as a possible source on the basis of data presented here, 
and the (more?) common presence of lead in Faynan copper ingots (Hauptmann et al., 1992, 2015) may favour such an interpretation. Higher levels of $\mathrm{Pb}$ (and $\mathrm{Co}$ ) were used by Segal et al. (1999) to distinguish Faynan from Timna as a source for ("Intermediate Bronze Age") ingots found in the Central Negev (Israel), a distinction that is impossible to make on the basis of LI data alone. Yahalom-Mack et al. (2014) similarly identified the origin of (Iron Age) loafshaped ingots from Neve Yam and an Intermediate Bronze Age bar ingot from Hazor (Israel) as Faynan rather than Timna on the basis of Pb content (ca. 1.5-3 wt\%), lead being typically lower in plano-convex Timna ingots (ca. 0-1.5 wt\% $\mathrm{Pb}$ ). Given this juxtaposition of inconclusive chemical, LI and broader archaeological arguments, a tentative 'Arabah copper' interpretation is maintained for these Pi-Ramesse samples.

Sample 1987_0512 is isotopically similar to these three casting spills and may equally match Timna or Faynan but has a relatively low lead content (only $0.3 \%$ ), which may favour a Timna interpretation. Being a ready-to-recycle dagger (bent, broken edges) from an earlier QI-B/3 context, it most likely represents a different 'batch' of copper from that discussed above, for which an Omani provenance is equally, if not more plausible (section 3.6).

The MBS (Massive Brown Sandstone) Faynan ores (the 'tail' of the Faynan data: high 207${ }^{206} \mathrm{~Pb} /{ }^{204} \mathrm{~Pb}$, low ${ }^{208-207} \mathrm{~Pb} /{ }^{206} \mathrm{~Pb}$ ) were not exploited during the LBA and can virtually be excluded for any Pi-Ramesse copper.

\subsection{Largest group - 'Egyptian metal'?}

The largest cluster of samples (around $15.67-15.70{ }^{207} \mathrm{~Pb} /{ }^{204} \mathrm{~Pb}, 18.88-18.95{ }^{206} \mathrm{~Pb} /{ }^{204} \mathrm{~Pb}, 0.828$ $0.831{ }^{207} \mathrm{~Pb} /{ }^{206} \mathrm{~Pb}$ and $2.056-2.061{ }^{208} \mathrm{~Pb} /{ }^{206} \mathrm{~Pb}$ ) shows striking similarity to one of the few available metal LI datasets available for Egypt: the bronzes from Amarna (Stos-Gale et al., 1995a), chronologically separated from Pi-Ramesse by only about 50 years. These are plotted alongside the Pi-Ramesse copper in Figure 6, together with contemporary Egyptian blue samples from the Ramesside fortress at Zawiyet Umm el-Rakham (Shortland, 2006). These three groups show close resemblance in their LI composition, though a slightly larger spread (15.66-15.71 ${ }^{207} \mathrm{~Pb} /{ }^{204} \mathrm{~Pb}, 18.73-18.99{ }^{206} \mathrm{~Pb} /{ }^{204} \mathrm{~Pb}, 0.827-0.837{ }^{207} \mathrm{~Pb} /{ }^{206} \mathrm{~Pb}$ and $2.055-2.069$ $\left.{ }^{208} \mathrm{~Pb} /{ }^{206} \mathrm{~Pb}\right)$.

At the time of publication, Stos-Gale et al. (1995a) concluded that one of the Amarna samples might reflect Timna ores, while some overlapped with the Lavrion copper ores from Greece (Gale et al., 2007), and the majority could not be assigned to any known ore source. Though 
the Taurus 1A ores in Anatolia (Yener et al., 1991) appear to coincide with this 'unknown' end of the Amarna data (Philip et al., 2003), these are lead ores, and therefore not useful for comparison here. The Pi-Ramesse, Amarna and el-Rakham LI results are shown together with the Lavrion copper ore LI data (from Oxalid ${ }^{2}$ ) in Figure 6. This shows that, though a few copper samples match a few of the Lavrion copper ores, the majority does not coincide. In fact, the Lavrion copper ores clearly lie on a different axis from this 'Egyptian group' (Lavrion sitting below it in terms of ${ }^{206} \mathrm{~Pb} /{ }^{204} \mathrm{~Pb}$ and ${ }^{208} \mathrm{~Pb} /{ }^{206} \mathrm{~Pb}$ ), and offer a poor match: their similarity to some of these samples is likely coincidental.

Apart from Amarna, Maadi (Abdel-Motelib et al., 2012) and Tell el-Farkha (Rehren and Pernicka, 2014), discussed below, the only known published LI analysis of Egyptian metals is by Fleming (1982), who examined Late Period Egyptian bronzes $\left(8^{\text {th }}-5^{\text {th }}\right.$ century BCE) from Sanam abu Dom and Kawa (Upper Nile region) and Memphis (Lower Nile). These are leaded bronzes, such that their isotopic composition is dominated by that of the lead metal added to the alloy. Therefore, their comparison here is not very instructive.

Other Egyptian materials have been analysed for LI composition by Brill et al. (1974), El Goresy et al. (1998), Fleming (1982) and Shortland (2006), including lead and silver objects, a few ores, kohl, glass, faience, Egyptian blue and green frit. With the exception of Egyptian blue, LI ratios of these materials mostly reflect their dominant lead content. The kohl (eye-paint produced from galena), for example, conforms well to Red Sea coast lead ores (Shortland, 2006). These materials, however, offer no useful comparison for the Pi-Ramesse copper.

Some of the Egyptian blue samples from el-Rakham, a coastal fortress-town from the reign of Ramesses II at the western border of Egypt, have LI ratios similar to the Pi-Ramesse and Amarna copper, which could indicate the use of similar copper for their production. Shortland's (2006) conclusion that the copper used to produce these pigments (and the analysed Amarna copper) must have come from outside of Egypt must be revisited here in light of more recent investigations.

Abdel-Motelib et al. (2012) offer an overview of mining and smelting in the Egyptian Eastern Desert and Sinai. Notably, all mineralisations there appear very pure: they contain very low concentrations of arsenic, nickel, cobalt, bismuth, lead, silver and gold, and the same is, accordingly, to be expected of raw copper smelted from these ores. Though the majority of explored sites show evidence for Chalcolithic, Early and Middle Bronze Age exploitation (with

\footnotetext{
${ }^{2}$ Oxalid: Oxford Archaeological Lead Isotope Database (http://oxalid.arch.ox.ac.uk/). LI data drawn from several publications is brought together there (Stos-Gale and Gale, 2009). Most of the Lavrion copper ore data is, however, unpublished.
} 
Sinai being a likely candidate for copper provisioning in Tell el-Farkha: Rehren and Pernicka, 2014), there is evidence for significant LBA copper production as well. Specifically at Bir Nasib I, Abdel-Motelib et al. (2012) estimate that over 5000 tons of copper may have been produced during the New Kingdom, with ore probably coming from Wadi Umm Rinna, making it a major production area. It is therefore worth comparing LI data of these ore sources with copper from Pi-Ramesse, as shown in Figure 7.

There is no immediate overlap with the large sample group from Pi-Ramesse (and Amarna) for any of the ore samples, though they fall within the very broad LI range attested by these ores. The closest match is seen for a copper ore fragment found in Maadi, most likely brought in from Sinai (Maadi H31 II 5/4), dating to the Naqadian period ( $4^{\text {th }}$ millennium BCE). A copper fragment from Sheikh Muhsen (Early Bronze Age II) overlaps with one of the moderately highlead samples: given the pure nature of these ores, 'Arabah copper' is a more suitable candidate here. In general, the Sinai/Eastern Desert ores appear to plot both above and below the large Pi-Ramesse group in 'LI space'. It must be emphasised that Abdel-Motelib et al.'s data reflects a very large range of deposits (and associated LI ratios) and exploitation evidence spanning several millennia. Furthermore, they scatter widely along the geochemically expected trend lines, especially in the ratios normalized to ${ }^{204} \mathrm{~Pb}$. This suggests generally lower precisions of those ratios, but this does not significantly affect interpretations proposed in this paper. The most relevant site for New Kingdom Egypt, Bir Nasib I, is represented by only two (slag) samples. As such, Sinai/Eastern Desert ores cannot be excluded as possible candidate sources for this 'Egyptian metal group', but further evidence is needed for stronger arguments either way.

There is no other LI data available for Sinai/Eastern Desert copper ores, though deposits exist beyond those covered by Abdel-Motelib et al. (2012). Examples from geological literature include Abouzeid and Khalid (2011), Anwar (1964), Garson (1977) and Hussein and el Sharkawi (1990). Ancient exploitations are discussed by Abd El-Rahman et al. (2013), BeitArieh (1985), Chartier-Raymond et al. (1994), El Gayar and Jones (1989a,b), Garenne-Marot (1984), Hikade (1998, 2006, 2007), Klemm and Klemm (1994, 2013), Lucas (1962), Ogden (2000) and Shaw (1994, 1998). These deposits, occurring throughout most of the Eastern Desert and into Nubia, must be considered as potential sources for the copper used in PiRamesse, even though they cannot be directly compared here.

Data on Eastern Desert lead ores exists (Doe and Rohrbough (1977), Shortland (2006), StosFertner and Gale (1979) and Stos-Gale and Gale (1981)), which Shortland (2006) and Weeks et al. (2009) suggest may have LI characteristics similar to copper ores from a similar 
geological setting in that region. Such comparisons to LI data from lead ores are not made here, but better characterisation of these copper ores in the future may allow further testing of the hypothesis that (some of) the Pi-Ramesse copper derived from within Egypt's boundaries.

Further comparisons for this largest group of Pi-Ramesse with various Anatolian copper ores (Begemann et al., 2003; Seeliger et al., 1985; Wagner and Öztunali, 2000; Wagner et al., 1985, 1986, 1989; Yener et al., 1991) are shown in Figure 7. Though the LI compositions of certain Anatolian ores and slags (particularly from Sivas, Balikesir, Norsuntepe and western Anatolia (cfr. Besiktepe)) and the large Pi-Ramesse group are roughly similar, no real overlap exists. Furthermore, the mining evidence for these ores is limited, and confined to the mid- $4^{\text {th }}$ to early $3^{\text {rd }}$ millennium BCE, making them very unlikely candidates. This is particularly true considering the tense $13^{\text {th }}$ century BCE political situation between Egypt and the Hittite Empire, and the absence of evidence for Anatolian copper being traded in the eastern Mediterranean at this time.

Comparison with Omani copper ore LI ratios (Begemann et al. 2010) shows no overlap for the large Pi-Ramesse group (though some overlap with other Pi-Ramesse copper, discussed below), but some similarity exists to copper objects (Figure 7 - overview omitting Anatolian ores in Supplementary Materials). These date to the Wadi Suq period (2000-1250 BCE): out of those providing a close match to the 'Egyptian group', some derive from $13^{\text {th }}$ century BCE context, while the majority cannot be dated more precisely.

LI data for Sardinian and Cretan ores and objects (Oxalid), as well as Arabian Shield Massive Sulphide Deposits (Bokhari and Kramers, 1982), galena (Stacey et al., 1980) and whole rock data (Ellam et al., 1990), and metal artefacts from Yemen (Weeks et al., 2009) were compared (not shown here), but did not reveal close resemblance to the Pi-Ramesse samples. While it is possible that ore deposits in the Arabian Shield area (Saudi Arabia, Yemen) provided important copper supplies to the LBA eastern Mediterranean (Liu et al., 2015), this hypothesis cannot be further explored in absence of copper ore data.

Overall, this large group does not correspond directly to any of the 'well-known LBA copper suppliers' (Stos, 2009) mentioned above, though some similarity to Omani metals and broad resemblance to Sinai/Eastern Desert ores may be noted. However, its resemblance to contemporary material from Amarna and el-Rakham may suggest that it represents 'common' copper circulating in Egypt at that time (not necessarily equating Egyptian ore sources). This 'Egyptian group', for which no straightforward identification is possible, is discussed further below. 


\subsection{Intermezzo: chemical composition of copper alloys}

Before continuing the discussion on LI ratios for the remaining samples, some comments on chemical compositions are offered. It must be noted that chemical heterogeneity within a single crucible batch, as witnessed in the Pi-Ramesse crucible prills due to strongly varying redoxconditions (Rademakers and Rehren, 2016) and inhomogeneous copper ingots (Hauptmann et $a l ., 2015)$, could be reflected in different casting spills. Furthermore, corrosion of several copper fragments may have distorted their original composition and the sensitivity of different elements to process-related changes in the course of their technological trajectory (oxidation, volatilisation, geochemical behaviour, etc.) can obscure their initial relations from the ore. Finally, the number of samples analysed (especially by NAA) is limited. Therefore, only tentative conclusions are drawn here.

Tin content averages at 10-11\% (see Figure 8). However, three casting spills consist of unalloyed copper, and furthermore have low (below detection limits) lead contents (unlike any alloyed samples). In terms of LI composition, they mainly plot intermediate to the samples discussed so far (Figure 4). The two crucible prills and isotopically consistent oxhide ingot fragment similarly exhibit very low lead contents. The former also contain a little tin content above the detection limit, but this may be due to contamination in the crucible. This coincidence of low lead and tin content (Figure 8, bottom) is remarkable, and concerns ca. $23 \%$ of the samples.

The unalloyed samples also exhibit low gold contents: $<10 \mu \mathrm{g} / \mathrm{g}$ for samples 1984_1162,1 and 1985_0205, while the average gold content in the bronze samples is ca. $100 \mu \mathrm{g} / \mathrm{g}$ (NAA data available for only 7 samples). This could point to the presence of ca. $100 \mu \mathrm{g} / \mathrm{g}$ gold in most copper used at Pi-Ramesse, with the exception of these few instances (Ogden (2000) notes recurring association of gold and copper ores in the Eastern Desert and Nubia). However, it appears more likely that the tin used for alloying at Pi-Ramesse contained traces of gold, which is thus measured in most bronzes. This would be consistent with the proposed use of alluvial cassiterite from the Eastern Desert in a cementation process for bronze production (Rademakers et al., in press). A similar argument was made for gold content noted in the Amarna bronzes by Stos-Gale et al. (1995a) (referring to alluvial tin and gold deposits of Abu Dabbab).

0.2\% gold (XRF) was measured in a bronze uraeus (1982_0219b) which was once gilded (surface layer lost through corrosion). Such objects might have been indiscriminately remelted 
in the Pi-Ramesse crucibles (the incomplete uraeus may have been considered scrap, or needed mending after being broken), as indicated by copper-gold prills found in one mounted crucible section (Rademakers, 2015). The rarity of gold in both crucibles and metals suggests that it was not intentionally or actively processed in the bronze workshops at Pi-Ramesse (though it was probably worked elsewhere in the capital: Pusch, 1999).

The lead contents of all samples are summarised in Figure 8. With the exception of four samples with strongly elevated lead content (around 5\% and 2\%), all bronze samples have lead contents of ca. $0.5 \%$, which most likely indicates its presence as an unintentional contaminant of copper (up to ca. 1\%: most likely from the smelting process (Pernicka et al., 1990), though possibly from repeated recycling of (moderately) leaded copper), rather than its intentional alloying (where a normal distribution around a value exceeding $1 \%$ is expected).

High iron content $\left(7.5 \%\right.$ by NAA, $4.4 \%$ by XRF) is noted in sample $1985 \_0205$. Moderate $(>0.5 \%,<1 \%)$ to low $(<0.5 \%)$ iron contents can be noted in most other samples (below detection limits for the nine Isotrace samples), with measurable cobalt content in ten samples. This iron (and cobalt) content results from ore compositions, primary smelting conditions and refining/recycling processes. These different samples thus may have gone through different technological trajectories before deposition, as well as post-depositional corrosion, and their absolute contents can therefore not be directly compared. The pattern for iron and cobalt (Figure 8) is similar to that seen for lead, indicative of their presence as a contaminant in the copper (ore), depleted throughout metallurgical operations. This matches very well the results from crucible slag analysis concerning iron and cobalt (Rademakers et al., in press): some ironrich copper was used, which did not contain significant cobalt, while some copper had significant cobalt content, invariably accompanied by iron. This is mirrored in the metal samples (Figure 8, bottom). The variable presence of cobalt (with iron) points to the use of copper smelted from cobalt-bearing ores whose Co-contents are difficult to assess. Though only trace levels are noted in these metal samples, several crucibles contain copper prills with 1-2 wt $\%$ Co and in one crucible 6-24\% Co (with 26-46\% Ni). This suggests cobalt was present at variable levels in one or more copper sources present in Pi-Ramesse, and partitioned into the crucible slag to varying degrees, albeit never completely. The absence of cobalt in other samples is most likely indicative of their origin from (nearly) cobalt-free ores.

Further bi-plots of arsenic, nickel, cobalt, antimony, iron, lead, tin, zinc, silver and gold content are shown in the Supplementary Materials. Overall, these elements (with the exception of tin) 
are present at contaminant levels. Given that there appear to be several sources of metal introduced into these crucibles, their individual chemical characteristics cannot be teased out of this necessarily limited sample. The tenuous relation between these chemical patterns and groupings based on LI ratios is returned to in the final discussion.

\subsection{Remaining copper alloys}

With this information in mind, the remaining LI samples are considered. So far, an ingot fragment and two crucible prills were identified as Cypriot (Apliki) copper, three moderately leaded samples as 'Arabah copper' (and one with lower lead content, close in LI composition), and a large group tentatively described as 'domestic copper'. The high-lead (5\%) and high-iron (7.5\%) samples are both outliers (LI ratios and elemental composition), while the remaining six samples are intermediate with respect to these three tentatively identified groupings.

The high lead content in sample 1984_1381 may indicate intentional alloying to produce a leaded bronze $(5 \% \mathrm{Sn})$ or the use of copper smelted from a lead-rich ore. Its typology (a 'round rod' fragment) provides no further clues as to why a leaded bronze would have been selected here. The lack of indications for intentional leaded bronze alloying in the Pi-Ramesse crucibles, coupled with the scarcity of leaded bronze use in Egypt as a whole for this period, suggests that its use as an intentional alloy is in fact doubtful here.

It may have been produced as an intentionally leaded bronze elsewhere, and subsequently reused in Pi-Ramesse. At 5\% lead, the lead content from the copper would provide only a limited contribution to the LI ratios of the leaded bronze, and this final composition is mostly reflective of a (non-Egyptian) lead ore.

Alternatively, raw copper with an exceptionally high lead content may have been used in its manufacture. The low iron content in this sample suggests that, in this scenario, the raw copper would have been refined before/during tin alloying. As much lead would be lost during refining, this alternative appears less likely.

Whether this particular object was brought into Pi-Ramesse from abroad ready-made or fabricated in the Ramesside workshops using foreign (lead-rich) copper remains unknown. Most likely, however, the higher lead content was not specifically aimed for in the Pi-Ramesse workshops. Though a good LI ratio correspondence exists for this sample with north-Anatolian ores (from Tekmezar: Begemann et al., 2003), no mining evidence exists for that region. A good ore match for this particular sample therefore remains unavailable for now. 
The iron-rich sample (1985_0205, with significant - ca. $600 \mu \mathrm{g} / \mathrm{g}$ - Co) contains no tin and lead (below detection limits), extremely low silver and gold contents $(7 \mu \mathrm{g} / \mathrm{g}$ and $2 \mu \mathrm{g} / \mathrm{g}$ by NAA respectively), and above average zinc content (263 ppm by NAA). Copper with such high iron content typically forms a significant and notable dross layer on top of the crucible charge upon melting (Merkel, 1990), as noted in at least one Pi-Ramesse crucible, and considerable iron enrichment builds up in the crucible slag. This sample falls within the LI range of Sinai/Eastern Desert and Omani copper (ores), though neither overlaps perfectly. Chemically, the latter provides a more likely match.

Some of the other intermediate samples could be identified as Limassol copper (section 3.1). A better correspondence exists, however, with Omani copper ores and metals from Middle to Late Bronze Age Wadi Suq. As Figure 7 shows, some of these samples are consistent with these Omani ore and metal samples (full range not shown), as are a few of the 'domestic copper' samples (section 3.3). 'Dirty' export ingots produced from this copper source with increased cobalt (and nickel) content could provide a good explanation for iron/cobalt-bearing intermediate samples. The absence of cobalt in the other intermediates means that the 'cleaner' Sinai/Eastern Desert copper ores cannot be excluded as a possible (additional) source.

For the (QIV) sample intermediate to Cypriot and 'domestic' copper (1992_0905, which overlaps with Lavrion copper, Figure 6, but has low $\mathrm{Pb}$ content), it could be suggested that its LI composition is the result of mixing 'domestic copper' and Apliki copper. However, the resulting lead content in the bronze is only $0.02 \%$, which would indicate a very minor contribution from the 'domestic copper' (typical lead contents of about $0.5 \%$ ). Alternatively, it may be suggested that adding $11 \%$ tin (with unknown lead content and isotopic composition) to Apliki copper was sufficient to pull it away from the Apliki LI range. Lead contents for Eastern Desert cassiterite have never been measured, but typical lead contents for contemporary tin ingots are in the 10-100 $\mu \mathrm{g} / \mathrm{g}$ range (Galili et al., 2013). Exceptions exist, however, with 600-1200 $\mu \mathrm{g} / \mathrm{g}$ Pb measured in some ingots (Begemann et al., 1999; Molofsky et al., 2014). Their addition to a virtually lead-free (Apliki) copper would introduce lead in the $0.01 \%$ range (for $10 \%$ tin). In such a scenario, the resulting bronze LI ratios are shifted away from those of Apliki copper and perhaps entirely dominated by those of the tin (Molofsky et al. (2014) discuss this principle for other case studies). From this perspective, the very low level of tin in the sampled area of crucible 1997_0690 (section 4.1), which contained the Apliki-consistent copper prill, may be the reason its Apliki signature was preserved. Though this does not confirm tin as the culprit in effectively 'hiding' Apliki copper in (bronze) LI 
studies, it may hopefully generate curiosity for future research, particularly experimental work on bronze alloying and recycling effects on resulting LI compositions, to investigate this hypothesis beyond the single sample presented here.

\subsection{Summary}

Though overlap of Sinai/Eastern Desert ores exists with nearly the entire range of metals attested at Pi-Ramesse, this does not weaken the identification of certain materials as deriving from different sources. The integration of chemical (e.g., lead and iron content), typological (e.g., oxhide ingot) and contextual information allows the distinction of probably four different metal sources within the Pi-Ramesse workshops, as shown in the final overview of Figure 9: Cypriot, Arabah, Omani (and possibly Sinai/Eastern Desert) and 'domestic copper'.

The contextual distribution of these samples reveals some interesting patterns. In Figure 10, a distinction is made between the QI industrial workshops (phase B/3) and later (phase B/2) finds from this northern QI area, the QI multifunctional workshops (phase B/2) and the QIV (phase B/2) workshop, following the colour-code of Figure 2. The possibility of some stratigraphic mixing, particularly for QI north, must be considered: some of the QI-B/2 samples may in fact belong to QI-B/3 (E. Pusch, pers. comm.). Figure 10 further highlights the five most iron-rich samples.

The QI industrial workshops appear to have mainly used 'domestic copper', while Cypriot ingot copper occurs in the same area only in phase B/2 and contemporarily in QIV. The intermediate Apliki - 'domestic copper' sample similarly derives from the QIV workshop, and lead-rich 'Arabah copper' appears exclusively in the QIV workshop. A (15\% tin bronze) bent dagger from QI may equally represent 'Arabah copper', but its lower lead content and different dating $(\mathrm{B} / 3$ rather than $\mathrm{B} / 2)$ suggests that it does not belong to the same 'batch' as the copper attested in QIV. An Omani provenance may equally be suggested here, as good LI agreement exists with a Wadi Suq copper spearhead. It is of the "Syrian tang dagger" type, a shape imported to Egypt from the Levant in the Middle Kingdom, but likely (though not certainly) produced in Egypt by the New Kingdom, at the peak of its popularity (Petschel, 2011). The fact that it is bent and battered suggests its (unfulfilled) destiny for recycling, similar to the folded dagger (86_0720) with 'intermediate' LI ratios (phase B/3, multifunctional workshops).

Perhaps most interestingly, the majority of remaining samples (casting spills and broken objects) belong to the QI multifunctional workshops (phases $\mathrm{B} / 2$ and $\mathrm{B} / 3$ ), and encompass 
intermediate and extreme LI compositions, as well as 'domestic copper'. This includes the five most iron-rich samples (three of which are tin-free) and the high-lead and gilded bronze samples. The intermediate LI compositions suggest the use of Omani copper in these workshops, though chemical variability of these 'intermediate samples' does not allow exclusion of a Sinai/Eastern Desert provenance for some. Iron-rich, raw copper $^{3}$ may have been refined in these workshops (until considered clean enough to alloy) and perhaps mixed with 'domestic copper'. One constituent of this 'domestic copper' may in fact be Omani and/ or Sinai/Eastern Desert copper as well, and its LI range may encompass some of the 'intermediate copper'. The concentration of more variable and 'dirty' copper in the multifunctional workshops may not be a coincidence, as discussed further below. No clear differentiation between phases $\mathrm{B} / 2$ and $\mathrm{B} / 3$ can be made from the presented sample.

\section{4 - Results: crucibles}

\subsection{Introduction}

The LI ratios for ceramic and slag of the Pi-Ramesse crucibles (see Rademakers and Rehren, 2016; Rademakers et al., in press) shown in Figure 11 cover a very similar range to those of the metal samples, but the nature of the data is quite different here. The ceramic part of the crucible, made of Nile silt, contains lead (averaging ca. $350 \mu \mathrm{g} / \mathrm{g}$ ) with strongly varying isotopic composition. No significant relation between lead content (varying between 20 and $1500 \mu \mathrm{g} / \mathrm{g}$ ) and its isotopic composition is discernible. This spread is assumed to be natural for the Egyptian Nile silt and reflective of the Nile basin geology, which draws on various upstream floodplains (see, e.g., Adamson et al., 1980; Foucault and Stanley, 1989; Garzanti et al., 2006; Krom et al., 2002; Said, 1981 and Stanley et al., 1988) and therefore represents a broad geological timescale. Specific publications on LI composition of these sediments do not exist.

In each crucible a slag layer is formed which has a certain lead content (average ca. 1.2\%, but strongly variable). This lead content is a mixture of lead from the molten ceramic and lead added into the slag from the molten charge. Therefore, LI ratios in the crucible slag are a mixture of those of lead in the ceramic and copper/bronze charge respectively. A line drawn in the three-dimensional space formed by LI ratios with the same denominator, going through the

\footnotetext{
${ }^{3}$ It should be kept in mind, however, that these casting spills are exactly that, and their iron content is therefore not necessarily representative of the crucible batch average.
} 
LI composition of the crucible ceramic and slag, should run through the LI composition of copper/bronze that was molten inside that crucible (Langmuir et al., 1978). The LI composition of the crucible slag would lie on this line intermediate to that of the ceramic and the metal $\left({ }^{207 / 206} \mathrm{~Pb}-{ }^{208 / 206} \mathrm{~Pb}\right.$ LI diagrams are of little use here, as natural correlation between these ratios generally produces a linear relation).

The relative contributions of lead to the slag by ceramic and metal are not just determined by their absolute lead contents, but additionally influenced by the degree of slagging of the ceramic, contact with the metal batch etc. For example, crucible slag LI ratios measured by Lehner et al. (2009) and Willet and Sayre (2006) - some of the few similar analyses - did not match their expected metal sources, which can probably be explained by a dominant ceramic contribution to slag lead content.

Other sources might contribute to the lead content in crucible slag. Tin could play a role (section 3.5), and fuel ash deriving from charcoal made of trees grown in lead-rich soil could be another example. Such effects have hitherto not been studied, but are most likely marginal with respect to the two main contributors: ceramic and metal. Under crucible operating conditions, lead contamination of the molten charge by the ceramic may be considered negligible.

When crucibles are reused to melt isotopically different copper, the resulting LI ratios of the crucible slag may present a mixed signal of these metals, making it impossible to use crucible slag LI ratios in the way proposed here. For the case study of Pi-Ramesse, however, crucible reuse is not an issue, as has been argued from complete assemblage analysis (Rademakers, 2015).

Theoretically, then, crucible LI ratios could be used to define LI ratios of metals molten in those crucibles. Obviously, the stronger the contribution of the ceramic is, the more difficult it is to propose such identifications. The analysis of lead contents for both ceramic and slag is therefore crucial to interpretations of their LI ratios: the difference between the slag and ceramic/metal is inversely proportional to their respective lead contributions.

There is, however, an important problem with the data presented here: LI ratios for the Nile silt appear strongly heterogeneous. Therefore, they might be variable within a single crucible, which complicates the principle outlined above. This is illustrated in Figure 12. In the ideal situation of silt with low lead concentrations and homogeneous LI signature and metal with 
comparatively high lead concentrations, one would obtain an almost horizontal trend on the right side of the diagram (low lead) and some variability on the left side dominated by the metal source(s). Here, the worst case for the discussion of mixing is presented, because both prerequisites are not fulfilled.

Indeed, there are two samples where the lead concentration is higher in the ceramic than in the slag. Incidentally, one of these is the only crucible (1997_0690) for which both ceramic and slag as well as an embedded prill (manually extracted from its crucible slag) were analysed. The prill has been identified as Apliki copper, characterised by very low lead (and tin) content, and significant iron and cobalt content. Conversely, the crucible slag is not strongly enriched in iron, cobalt or lead with respect to the ceramic as measured by SEM-EDS, though minor cobalt contamination is detected by NAA (Table 6). This points to limited interaction between the metal and crucible slag in the sampled area of this crucible (Rademakers and Rehren, 2016), which is further validated by the lead content decrease of the slag with respect to the ceramic: it has been diluted through melting of the ceramic (fluxed by fuel ash), without further enrichment from the metal charge. Even if there had been significant interaction between the charge and the crucible slag (possibly producing stronger iron/cobalt enrichments as noted in several Pi-Ramesse crucibles), the Apliki copper could have contributed very little lead to the slag. As a result, the slag LI composition for this crucible fragment is closer to that of the ceramic than to the metal prill. It can further be noted that the line connecting these three points in LI space is only approximately straight. This could be the result of other components contributing to the slag LI ratios but more likely reflects LI inhomogeneity of the crucible ceramic, which acts as the main lead contributor to this slag. This example highlights the importance of relative lead contributions in assessing slag LI ratios. As no prills are available for the other analysed crucibles ${ }^{4}$, conclusions have to be drawn from the ceramic and slag LI ratios.

With one further exception, lead contents of the slag are higher than those of the ceramic for the analysed crucibles. Figure 13 illustrates the relative lead change between ceramic and slag $\left(\Delta \mathrm{Pb}_{\text {rel }}=\left(\mathrm{Pb}_{\text {slag }}-\mathrm{Pb}_{\text {ceramic }}\right) /\left(\mathrm{Pb}_{\text {ceramic }}\right)\right)$, with respect to the relative change in copper content. $\Delta \mathrm{Cu}_{\text {rel }}$ reveals the integration of copper from the charge into the slag through the physical trapping of copper and its oxidation ('burning off') into the crucible slag. This is similarly true

\footnotetext{
${ }^{4}$ Sample MA-131735 is another crucible prill extracted from a fragment of crucible slag. The analysed crucible ceramic and slag MA-131733-4 were taken from a different fragment from the same find bag (87_0897a,01-45), and cannot be securely related to this prill.
} 
for $\Delta \mathrm{Pb}_{\text {rel, }}$, with the difference that lead oxidises more readily into the slag than copper, but less readily than tin (Ellingham, 1944). It is therefore safe to assume that, if the crucible slag is relatively enriched in both copper and tin, the charge's lead content will be reflected in the slag as well. However, lead/copper ratios may differ (strongly) between the slag and charge. Discussion of the remaining crucibles is organised following these considerations.

\subsection{Strong interaction, high lead content}

In three crucibles (1987_0762,0Nv, 1997_0631E,01 and 1997_0631E,04), there is a significant relative increase in lead content (ca. $\Delta \mathrm{Pb}_{\text {rel }}=140-620$ ), which is accompanied by ca. $\Delta \mathrm{Cu}_{\text {rel }}=10-110$ and $\Delta \mathrm{Sn}_{\text {rel }}=140-1000$. This indicates good slag-charge interactions, as well as relatively high lead content of the crucible charge $\left(\Delta \mathrm{Pb} \mathrm{b}_{\mathrm{rel}} / \Delta \mathrm{Cu}\right.$ rel $\left.=5-60\right)$. The LI ratios for the slag of these three crucibles all fall within the Faynan/Timna range, and close to the three lead-rich metal spills discussed in section 3.2.

Important lead contamination of the crucible slag was similarly noted for these crucibles by SEM-EDS. Interestingly, however, the 'Arabah copper' identified in the metal spills was fairly free of iron, whereas one of these crucibles shows notable iron contamination of the slag, indicating the use of incompletely refined copper. This could suggest the use of multiple 'batches' of 'Arabah copper' in Pi-Ramesse, or simply variability of iron content within a batch and throughout the crucible alloying process (raw, molten, spilled and cast copper/bronze), which (partially) refined the copper.

It therefore seems appropriate to suggest here that these crucibles, all from phase $B / 2$, were used to melt the same (type of) 'Arabah copper' found in the three casting spills (equally phase $\mathrm{B} / 2$ ). The crucibles show, however, that this copper is not exclusive to the QIV workshop, as the metal remains would suggest, but was equally employed in the multifunctional workshops in area QI.

\subsection{Medium-strong interaction, low lead content}

In two crucibles (1987_0634c and 1987_0897a, "medium Pb" in Figure 13), a high level of slag-charge interaction is attested (ca. $\Delta \mathrm{Cu}_{\mathrm{rel}}=60-130$ and $\Delta \mathrm{Sn}_{\text {rel }}=190-200$ ), but relative lead enrichment is much lower (ca. $\Delta \mathrm{Pb}_{\text {rel }}=20-30$ ), demonstrating relatively low lead in the crucible charge $\left(\Delta \mathrm{Pb}_{\mathrm{rel}} / \Delta \mathrm{Cu}_{\mathrm{rel}}=0.15-0.47\right)$. 
In another three crucibles (1983_0542b, 1983_05971 and 1987_0762, "low Pb" in Figure 13), the relative lead enrichment is slightly lower (ca. $\Delta \mathrm{Pb}_{\text {rel }}=13-20$ ), paired with weaker slagcharge interaction (ca. $\Delta \mathrm{Cu}_{\mathrm{rel}}=7-30$ and $\Delta \mathrm{Sn}_{\text {rel }}=0.01-106$ ). It is therefore even more difficult to assess the lead content of the crucible charge $\left(\Delta \mathrm{Pb} b_{\text {rel }} / \Delta \mathrm{Cu}_{\text {rel }}=0.66-1.87\right)$.

If melting/fluxing of the ceramic indeed lowers slag lead contents through dilution, as suggested in section 4.1, then relative increases in slag lead content point to charge

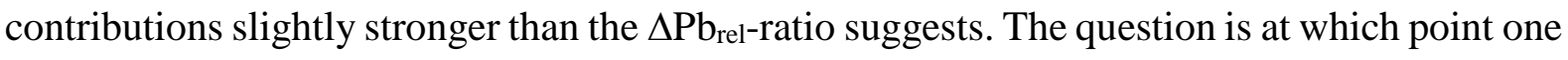
can consider the charge contribution to be "dominant". Or better, when does the orientation of the ceramic-slag-charge mixing line (strongly influenced here by variability of the ceramic LI ratios) become irrelevant, and can the crucible slag's LI ratios be considered a good approximation to those of the charge?

In these five crucible samples, the slags are ca. 13-30 times closer to their crucible charge in terms of LI ratios. Taking, as an extreme example, the maximum range attested for ${ }^{207 / 204} \mathrm{~Pb}$ (ca. 0.175) in the Pi-Ramesse copper samples, the low-lead slags would be $\leq 0.0125$ away from the charge in terms of ${ }^{207 / 204} \mathrm{~Pb}$, which is about an order of magnitude larger than the precision of measurement $(2 \sigma)$. For ${ }^{206 / 204} \mathrm{~Pb}$ and ${ }^{208 / 204} \mathrm{~Pb}$, this distance is ca. $10-70$ times $2 \sigma$. For $\Delta \mathrm{Pb}_{\mathrm{rel}}=30$, the distance remains 5-30 times $2 \sigma$. Only when the relative $\mathrm{Pb}$ enrichment of the slag is 100 or more, does the maximum theoretical distance between the LI ratios for crucible slag and charge approach measurement precisions. This shows that the slag LI ratios remain only a rough estimate of the charge's LI ratios, particularly when relative $\mathrm{Pb}$ enrichments of the slag are low. Even when they are slightly higher, estimates for the charge LI ratios remain highly tenuous when the 'background' metal LI data, available in this particular case study, is removed. Particularly in cases where the crucible charge may have more extreme (radiogenic) LI ratios (which are unknown), the crucible slag LI ratios offer only very imprecise estimates for those of the charge.

With these considerations in mind, the slag LI ratios of 1987_0634c and 1987_0897a can be reconsidered. Sample 1987_0634c plots squarely within the 'domestic group'. Despite large imprecision, it is very likely that this identification holds for the crucible charge, given the isotopic range proposed for the 'domestic group'. It shows limited contamination and conforms with Sinai/Eastern Desert (or much recycled) copper. For 1987_0897a, the slag LI ratios fall close to one of the 'intermediate' copper samples, but relatively close to the 'domestic group'. 
Interestingly, this slag is noticeably enriched in iron (SEM-EDS), cobalt (SEM-EDS, NAA) and Ni/As (NAA) - more congruent with expectations for Omani copper (cfr. section 3.5).

For crucible 1983_05971, which may be slightly more $\mathrm{Pb}$-enriched than it appears ${ }^{5}\left(\Delta \mathrm{Pb}_{\text {rel }}=20\right)$, the slag LI ratios almost perfectly overlap with bronze sample 1987_0512 (section 3.2). The potentially large discrepancy between slag and charge LI ratios, however, renders this identification very tentative. The slag contamination pattern (in terms of $\mathrm{Co}, \mathrm{Ni}, \mathrm{As}, \mathrm{Ag}, \mathrm{Sb}$ and $\mathrm{Pb}$ ) compared to that of crucibles discussed in section 4.2, suggests a copper source different from the Pb-rich 'Arabah copper' for crucible 1983_05971 (used in the multifunctional workshops of QI (south), phase B/2), which might be the same as sample 1987_0512 (a dagger from the industrial area QI-B/3). This is only poor inference, however, which would be impossible without the benefit of copper LI data presented earlier.

For crucible 1983_0542b and 1987_0762 (ca. $\Delta \mathrm{Pb}_{\text {rel }}=13$ ), the slag LI ratios both fall in the 'intermediate' (QI-c/4.5) copper range (section 3.5). The increased uncertainty on the comparability of slag and charge LI ratios for these two crucibles, however, discredits any comparison to metal LI ratios. 1983_0542b reveals no significant slag contamination of any kind (NAA or SEM-EDS), while 1987_0762 is characterised by low but significant cobalt, nickel and arsenic contamination (NAA), with relative iron and cobalt increases noted by SEMEDS.

\subsection{Weak interaction}

The four remaining crucibles (1983_1149b, 1987_0942g, 1997_0690 and 1998_0387) reveal much lower slag-charge interaction (ca. $\Delta \mathrm{Cu}_{\text {rel }}=1.5-11$ and $\Delta \mathrm{Sn}_{\text {rel }}=0.2-3.5$ ), accompanied by (very) low (ca. $\Delta \mathrm{Pb}_{\text {rel }}=0.5-2.7$, "no $\mathrm{Pb}$ " in Figure 13) and even negative (ca. $\Delta \mathrm{Pb}_{\text {rel }}=0-$ 12, "negative $\mathrm{Pb}$ " in Figure 13) changes in lead content. In this situation, it becomes impossible to distil the lead content and contribution of the charge to the crucible slag from the data (cfr. section 4.1: Apliki copper in crucible 1997_0690). Discussion of their slag LI ratios is therefore omitted here. The weak crucible-charge interactions similarly limit slag contamination in terms of trace elements, and indeed no significant contamination was revealed by SEM-EDS for these crucibles (two of which are rim fragments, for which limited interaction is expected:

\footnotetext{
${ }^{5}$ The low tin slag enrichment in crucible 83_05971 appears to be related to a contamination of the ceramic, which has unusually high $\mathrm{Sn}$ contents (as well as $\mathrm{Sb}, \mathrm{Co}, \mathrm{Ni}, \mathrm{Ag}$, and $\mathrm{Pb}$ contents) relative to other measured ceramics (though normal $\mathrm{Cu}$ content).
} 
Rademakers and Rehren, 2016). NAA did, however, reveal some cobalt (1987_0942g, 1998_0387) and minor nickel (all four) contamination, but this information is not very helpful here.

Finally, the slag sample of crucible 87_0726,68-78b, for which no ceramic crucible exterior was archaeologically preserved, may be considered ("Slag only" in Figure 13). Its crucible slag is characterised by high iron enrichments and iron-rich bronze prills (SEM-EDS), as well as very high copper and tin contents (the highest in Table 6), indicative of strong crucible-charge interaction, and the use of raw or poorly refined copper. The $1160 \mu \mathrm{g} / \mathrm{g}$ lead in the crucible slag may therefore be reflective of the crucible charge to some degree. The LI ratios suggest the use of an "intermediate copper", with increased nickel and arsenic content relative to the ceramic average.

\subsection{Chemical analysis}

The results in Table 6 offer only limited insights, as these data do not represent bulk chemistry, but rather ceramic and slag contaminants. As chemical heterogeneity has been noted for isotopically similar copper attested at Pi-Ramesse, these contaminants do not help the interpretation of samples discussed above where LI analysis is inconclusive. Cobalt, nickel, arsenic and antimony in the crucible slag show only limited correlation, which may be attributed to their varying geological occurrence in the different attested copper ores, and the different technological trajectories to which they were subjected before melting in Pi-Ramesse. The sample size for each isotopically defined group is too small to confidently characterise them chemically.

The presence of gold correlates quite well with that of tin, as was previously remarked for the copper samples and further supports the suggested use of relatively gold-rich alluvial cassiterite (possibly from the Eastern Desert) for bronze alloying through cementation.

While elements such as silver, arsenic, cobalt, nickel and antimony are related to particular ore deposits, the iron content is more related to the primary smelting processes (Craddock and Meeks, 1987) and subsequent refining, and can therefore aid in identifying metal "batches", as argued further below. 


\section{5 - Discussion}

The scale of bronze production archaeologically attested in Pi-Ramesse suggests that several tons of metal were processed in the various Ramesside workshops. Discovery of both scrap and ingot copper proves that multiple sources of copper were being used to answer the workshops' need for copper. Analysis of the Pi-Ramesse crucibles has indeed shown a combination of bronze recycling and fresh alloying to have taken place in the workshops (Rademakers et al., in press). Association of (trace) gold with tin in both metal and crucible slag data presented here corroborates the tentatively identified use of alluvial cassiterite in a bronze cementation process. This paper aims to elucidate the variety of sources on which the Egyptian craftspeople relied in these particular workshops. The results presented in the previous sections suggest that several sources indeed existed, though not all of them may currently be precisely identified.

Most securely identified is the use of Cypriot oxhide ingot and Arabah copper. This appears to account for only a minor fraction of copper use, however, confined to the workshops of (nonindustrial) phase $\mathrm{B} / 2$ in areas QI and QIV. The isotopically prolific group of copper was used everywhere, but predominantly in the industrial workshops (QI-B/3), and has been tentatively identified as 'domestic copper'. Finally, a group of 'intermediate samples' with more strongly varying LI compositions occurs, primarily in the multifunctional workshops (QI-B/2), which may largely represent copper from Oman and perhaps Sinai/Eastern Desert, but further includes recycled and possibly mixed copper/bronze.

It is remarkable that Apliki copper has only been noted in its ingot form and as two prills trapped in crucible slag, but not in any objects. In fact, it has not been noted in any objects throughout the LBA Mediterranean at all (with the exception of Cypriot artefacts: Gale and Stos-Gale, 2012), resulting in speculation that ingots were never molten down and cast into objects (a position which is arguably difficult to maintain, surrounded by exhaustive debate: e.g. Budd et al. (1995) and comments), and that, in particular contexts, (fragments of) ingots might have functioned as currency or cult objects (e.g., Lo Schiavo et al., 2013, 51-52). Its discovery in two Pi-Ramesse crucibles is therefore a major one. However, their preservation precisely in crucible slag begs further attention. Do these prills represent Apliki copper only because they did not interact further with the crucible charge, as suggested by their low tin contents? Apliki copper's low lead content may regularly be overshadowed by the lead content of any tin added during alloying, even if that lead content is only minor, and thus become 
invisible to archaeologists. Its abundance in Pi-Ramesse may therefore be underestimated from the results presented here, as perhaps exemplified by the 'intermediate Apliki-domestic copper' sample (section 3.5). When mixed with other copper, such a scenario seems especially likely. This may indeed explain the apparent dearth of Apliki copper in LBA bronzes, despite its widespread trade (Gale, 2011), and sheds new light on a long-existing mystery. A similar argument for Apliki copper's disappearance in the crucible was made by Muhly $(2003,2009)$, though his suggested responsibility of 'Lavrion lead contamination' is unnecessary for PiRamesse.

The discovery of 'Arabah copper' in Pi-Ramesse, both in the metal spills and crucibles (indirectly by lead enrichment of the crucible slag in ca. $15 \%$ of the complete assemblage and in crucible slag LI ratios), is not a first for Egypt (Stos-Gale et al., 1995a), but offers important physical confirmation of contact with this neighbouring region. Ongoing excavations in both Timna and Faynan are currently refining chronologies for ore exploitation there (Ben-Yosef et al., 2012), which may hopefully soon be coupled to well-contextualised metallurgical analysis to clarify diachronic changes in smelting technology and resulting raw copper compositions. Linked with an expansion of LI and chemical analysis of Egyptian copper artefacts, this may reveal more detail on interactions between Egypt and the different areas within the Arabah valley. For now, the exact origin of Arabah imports at Pi-Ramesse must remain unclear.

The major group of Pi-Ramesse samples, representing approximately half of the population, has been labelled 'domestic group', due to its LI similarity to the majority of analysed metals from Amarna and some Egyptian blue cakes from el-Rakham: both roughly contemporary sites in Egypt. As such, it is suggested that this area in 'LI space' may be typical for (recycled?) copper circulating in New Kingdom Egypt, though very limited comparative data is currently available to test this hypothesis.

This 'domestic copper group' is not uniquely consistent with any contemporarily mined copper ores from the eastern Mediterranean currently known, though it falls within the broader range of Sinai/Eastern Desert ores, as well as some Omani and Anatolian copper ores. These Anatolian ores are unlikely candidates (section 3.3), while chemical data suggests both Omani and Sinai/Eastern Desert ores may constitute this group. This group's isotopic clustering may thus be explained by the LI ratio overlap of copper smelted from distinct ores, offset by chemical heterogeneity related to their different chemistry (relatively 'clean' Sinai/Eastern Desert ores and As/Co/Ni-richer Omani ores), which appears diluted in the copper through 
various metallurgical operations (possibly including mixing, which would tend to reduce the spread in LI ratios).

The (admittedly limited) current evidence indicates that early Egyptians relied at least to some degree on production from the Eastern Desert and Sinai in their provision of copper. Mining evidence further shows that production continuity exists in this region at least up until Middle Kingdom times. Even during the New Kingdom, there was large scale copper production at Bir Nasib, South Sinai, as well as copper/gold exploitation in the Eastern Desert. Altogether, there is fairly compelling evidence to suggest that domestically produced copper, coming from the Eastern Desert and/or Sinai, would have been in circulation in Egypt throughout its pharaonic history (Rademakers et al., in press, Rehren and Pusch, 2012). This copper, already attested early on in Maadi and Tell el-Farkha, would have probably been regularly replenished with freshly mined copper from these ores, as well as (perhaps more occasional) copper from abroad. Here, the most likely candidates for long-time contribution are Timna/Faynan and trade partners along the Red Sea coast, while sources from further away are expectedly minor contributors, at least up until the LBA. As such, the 'domestic group' should not be seen as entirely distinct from the 'intermediate samples', which may further belong to the circulating metal spectrum, as supported by the contemporary Amarna and el-Rakham artefact LI range.

Overall, a fairly closed system may be imagined here (contrary to the wider eastern Mediterranean as whole), similar to suggestions made for Sardinia by Pinarelli (2004). It is highly likely that at least some of this domestically circulating copper (mainstream and scrap copper, as defined by Rehren and Pusch (2012)) was used in Pi-Ramesse (and Amarna) and should therefore be reflected in the LI field presented here. This is strongly suggested by the recycling of metal tools in the (B/2) Pi-Ramesse workshops (Prell, 2011), the exchange and hoarding of scrap metal (Gestoso Singer, 2015) and by the tight control over metal tools witnessed, e.g., at Deir el-Medina (Eccleston and Kemp, 2008). The general attitude of ancient Egyptians (particularly the pharaonic state itself) towards (precious) resources seems to have been quite frugal, favouring a system of internal recycling.

Jaksch et al. (1983) argue that the copper source for (New Kingdom) Egyptian blue may largely have been scrap bronze, which Thomas (2000: 227) suggests took place in state-controlled production centres. The isotopic similarity to several contemporary Egyptian blue samples thus provides another perspective on the 'domestic group'. In this context, the suggestion by Rehren et al. (2001) that Egyptian blue cakes were produced at Pi-Ramesse, and probably traded 
throughout Egypt, is particularly remarkable, as el-Rakham was likely "a receiver of trade goods from the centre" (Thomas, 2000: 321). This new LI data therefore reinforces suggested interconnections between the different high-temperature technologies and their provisioning networks at Pi-Ramesse and elsewhere in Egypt.

Our primary interpretation, then, for this sample group is that it to some extent represents this circulating copper, comprising copper freshly smelted from Sinai and Eastern Desert (extending into Nubia) ores, and (more limited) Arabah and Omani copper, as well as recycled, circulating metal (originally from these sources). The scrap metal analysed in this paper mainly falls in this 'domestic-intermediate range', supporting such an interpretation. The well-known Egyptian interactions along the Red Sea with the 'Land of Punt' (Dixon, 2004; Fattovich, 2012; Meeks, 2003) for various exotic materials including metals offer plausibility to an Omani connection: positioned on the Arabian Peninsula, with trade posts on both Arabian and African sides of the Red Sea, the 'Land of Punt' may have traded exported Omani copper. Being a long-term trade partner of pharaonic Egypt, its regular inclusion in metal circulating within Egypt would not be very surprising. Mesopotamia may present another possible route by which copper from Oman could have reached Egypt over time. Along the Red Sea, copper produced from ores on the north-western Arabian Peninsula and Yemen may equally have found its way into Egypt (though Egyptian metals might have travelled in the other direction as well: Weeks et al., 2009). Though no isotopic evidence is currently available to suggest this, this source is worth considering in the future (Liu et al., 2015).

It is hoped that this hypothesis for the 'domestic copper' can be further tested in the future with more extensive data from the various Sinai/Eastern Desert (and NW Arabian Peninsula) copper ores, as well as a better diachronic coverage of Egyptian metals throughout different social contexts. The $19^{\text {th }}$ Dynasty 'snapshot' presented in this paper cannot elucidate this any further. It can be noted, however, that the Sinai/Eastern Desert ores show such a large LI compositional range, that, even though no exact overlap with the Pi-Ramesse metal exists for the current ore samples, copper ores probably exist which match the 'domestic group' seen here, and are yet to be analysed. Nonetheless, the integration of recycling and possible mixing in a scenario of 'circulating domestic Egyptian copper' predicts that no exact ore match may ever be found.

It is crucial to emphasise that the scale of mixing in Pi-Ramesse is difficult to assess. The archaeological evidence for recycling in Pi-Ramesse is abundant, directly as scrap metal finds and indirectly in the crucible slag, and its representation in the discussed data may be expected. 
However, while large amounts of copper were molten simultaneously in separate crucibles to produce monumental castings (Pusch, 1990), these large final objects (the most likely candidates for mixed LI ratios) were not sampled. Instead, 'crucible batches' are most likely seen here, for which the volumes are more often representative of single ingot fragments or metal scraps. The presented data is therefore unlikely to represent mixing within Pi-Ramesse itself. Mixing within a larger system (e.g., Egypt) is possible, indeed likely, and would be reflected in scrap copper, but cannot be assessed without a much larger, diachronic sample. Though repeated copper mixing within Egypt would theoretically result in a more homogeneous clustering of the mixed material, both chemically ${ }^{6}$ and isotopically, the limited clustering seen in this small sample does not exclude mixing, especially if fresh material was regularly added to the copper circulating in Egypt.

Information on the provenance of metals is lost if copper from several sources should have been mixed. It has long been assumed that especially by the end of the LBA the fraction of recycled metals would increase and this could also explain the widespread occurrence of Lavrion-type LI ratios in bronzes, because even a minor part of leaded bronze with Lavrion signature within a large metal charge that was melted down would make its imprint. Insofar it should not be surprising to find that in such a large workshop as Pi-Ramesse mixing of metals and re-use of scrap metal took place. Therefore, as a final hypothesis for the 'domestic group', the addition of lead from Lavrion or even the Taurus mountains to a variety of copper sources, as suggested by Muhly (2003, 2009) and Stos-Gale et al. (1995a), resulting in bronzes with LI ratios dominated or contaminated by that added lead, cannot be firmly excluded for all samples on the basis of the presented chemical and isotopic data. However, this appears to be a less likely explanation for these samples, which form a 'grouping' unique to Egypt compared to the published LI corpus for Eastern Mediterranean copper and bronze. It thus more likely represents Egyptian scrap than 'general LBA eastern Mediterranean scrap', whose LI ratios (lead ores) it does not strictly conform to anyway. Furthermore, the hypothesis of LBA Lavrion lead contamination has been refuted in favour of Lavrion copper mining by Gale et al. (2007), while LBA Taurus lead is even less likely to have been an important contaminant for Egyptian copper (section 3.3). Therefore, this hypothesis should be considered in future investigations, but appears less likely than the one outlined above.

\footnotetext{
${ }^{6}$ Ideally, one would check if the spread of certain elements, such as As, $\mathrm{Sb}, \mathrm{Ni}$ and $\mathrm{Ag}$ is smaller in the 'domestic group' than in the Pi-Ramesse sample as a whole, but the number of samples presented here is too small to provide meaningful results.
} 
As noted in section 3, the possible existence of hitherto undiscovered copper ores mined in antiquity leaves the door open for future re-evaluation of all samples discussed here, as with all LI data. The above discussion has attempted to consider the most likely possibilities, including the potentially important contribution from uncharacterised Egyptian ores.

Whatever the geological source of these various metals may be, the most interesting conclusions with regards to the Pi-Ramesse workshops lie perhaps in the identification of different batches of copper arriving within the various workshops. The potential of "raw material batches" as an analytical category surpassing direct provenance has already shown significant potential in other studies of metal, glass and ceramic production (Freestone et al., 2009a,b, 2010; Martinón-Torres et al., 2014; Leusch et al. 2015; Martinón-Torres and UribeVillegas, 2015). Here, a distinction may be made between recycled copper and fresh copper.

The use of poorly refined copper is attested by crucible slag analysis in approximately half of the crucibles, and is twice more prevalent in phase $\mathrm{B} / 2$ than it is in phase $\mathrm{B} / 3$ (Rademakers, 2015). Crucibles with more iron enriched (ca. 35\% of the assemblage) or cobalt-iron enriched slag (ca. $15 \%$ of the assemblage) could be related to the use of more freshly smelted, less refined copper. This offers information on copper quality and 'freshness', but cannot be used to firmly relate crucibles to metals in terms of provenance. Strong variability in slag contamination within crucibles inhibits the use of trace elements in crucible slag for provenance means. Furthermore, the limited chemical data presented here reveals certain copper tentatively identified as 'Arabah', Apliki and possibly Omani all exhibit trace cobalt content, while cobalt is absent in others with similar LI ratios.

The Cypriot oxhide ingot, lead-rich 'Arabah copper' and iron-rich 'intermediate' (probably Omani) copper are the best examples of 'fresh copper'. Slight compositional variability of the crucible prills may indicate two different Apliki copper 'batches', or simply variability within a single batch. The 'Arabah copper' (again with minor compositional variability) sometimes contaminated the crucible slag with significant iron during melting, suggesting its initially unrefined state. This prevalence of more iron-rich raw copper in the multifunctional workshops is noted alongside the rarer recycling of gilded and lead-rich bronze.

In contrast, ca. $50 \%$ of the crucibles are characterised by little or no chemical contamination, indicating the use of a chemically pure copper source or better refined copper. Chemical purity, however, does not significantly correlate to any of the groups defined isotopically in this paper. The 'clean copper' may correspond in part to the suggested 'domestic copper', which may 
represent 'clean' Eastern Desert/Sinai copper and/or repeatedly recycled copper. The common use of 'domestic copper' in the industrial workshops is striking, and may reflect a variety of things. For example, the large industrial workshops may have relied heavily on 'familiar materials' to avoid casting problems related to possibly contaminated copper when melting over $100 \mathrm{~kg}$ of copper simultaneously through the concerted use of several melting batteries. In contrast, the multifunctional workshops, where a much lower, probably single-crucible scale of bronze production was undertaken, could afford the use of varied copper sources and the occasional need for refining 'on-the-go'. The amounts of copper consumed during such melting/alloying operations were much smaller as well. However, these trends may equally represent the arrival of copper shipments in the Ramesside capital through time, rather than its selection for a particular workshop setting. The number of samples here are too small to firmly establish such distinctions. Though fairly good agreement with the results from crucible analysis supports these ideas, they must serve as tentative suggestions for now. A much larger scale of Egyptian bronze LI analysis is required to assess these questions from a diachronic perspective, sensitive to variability across different production and consumption contexts. The workshops of Pi-Ramesse mainly represent a massive state-organised bronze production event, probably spanning a few weeks, followed by small-scale bronze production and repair. As such, the results presented here only offer a glimpse into a very complicated and varied picture of metal provisioning in ancient Egypt. It is hoped that they will inspire further research into this poorly studied aspect of Egyptian archaeology, and exemplify its importance in understanding copper trade in the wider LBA eastern Mediterranean.

In conclusion, this paper aims to contribute some more general methodological perspectives on crucible LI analysis. It is clear that the LI analysis of crucible slag cannot be equated to that of metals. A dominant lead contribution from the crucible charge to the slag is necessary for it to be representative of that crucible charge. This can only be inferred when the lead content of both crucible ceramic and slag is known. Problems may arise, however, when the lead content of the charged metal is low (e.g., Apliki copper) or when limited interaction has taken place between the crucible slag and charge (in the sampled crucible area). Therefore, analysis of the crucibles by means of mounted cross-sections is highly desirable and offers important understanding of the metallurgical technology (alloying vs. recycling, contaminant content of embedded prills etc.), which can aid in understanding the LI data and can furthermore suggest the likelihood of crucible reuse that can otherwise not be critically evaluated (Rademakers and Rehren, 2016). The confidence with which the slag LI data may then be interpreted as resulting 
from the interaction of crucible slag with a single metal is low. This pitfall is separate from the issue of metal mixing more generally: here we only discuss how representative crucible slag LI ratios can be of the metal charged in that particular crucible, regardless of that metal's LI ratios' interpretation. For the particular case of Pi-Ramesse, it has been argued that metal mixing in the crucibles themselves is unlikely given their relatively small volume, though the large castings, made up of several crucible charges, may have mixed LI ratios with respect to these individual crucible charges.

While a highly increased lead content of the crucible slag may provide confidence in its isotopic similarity to the charged metal, significant but less strong increases are difficult to interpret. Though they might be strongly drawn towards the metal charge on the mixing line between charge and ceramic, they do not necessarily coincide and it is difficult to infer the exact LI ratios of the charge. The absence of a reference body of LI data for metals discovered in the workshop from which the crucible assemblage derives strongly lowers the confidence of interpretations from crucible slag data. Though crucible analysis here did change some of the contextual interpretations (e.g., showing the presence of 'Arabah copper' in workshops were it was not detected in the metal samples), the presented LI data without the metal data are too imprecise to be useful. Another possible problem is the non-linearity of mixing lines between ceramic and charge due to possible ceramic LI heterogeneity.

These issues are important to bear in mind when contemplating future studies, and prompt the critical appraisal of crucible slag LI data previously published (e.g., Lehner et al., 2009; Liu et al., 2015; Willet and Sayre, 2006). Metal droplets isolated from crucible slag for analysis, such as those analysed by Ling et al. (2014), offer more reliable data though attention to lead content remains crucial. Ling et al. relate their period IV samples (45 and 46) to the fahlore deposits near Brixlegg in Tyrol which are notoriously low in lead (usually $1 \mathrm{mg} / \mathrm{kg}$ or less) while the two samples have ca. $0.2 \%$ lead and $0.26-1.08 \%$ tin. The low tin contents are best explained as indication of mixing of two or more components, which is consistent with their late date and would erase the information on provenance of the copper. The three period II crucible droplets have been shown to be also consistent with copper ores from Slovakia in their lead isotope ratios (Pernicka et al., 2016), which is a more reasonable origin than southern Spain or Sardinia. It is hoped that the results presented in this paper will provide a methodological aid not only to crucible interpretation, but equally the considered selection of promising samples for provenance studies of ancient metal. 
Though the aim of this methodological discussion is to one day overcome this problem, further case studies and the testing of principles outlined in this paper are necessary before the method can be considered sufficiently robust to apply with confidence for metal provenancing in the absence of metal samples. For now, we recommend the use of crucible slag lead isotope ratios only when the lead content of the slag has been shown to be at least 100 times that of the crucible ceramic, which should in turn ideally be homogeneous in its LI composition. Whenever possible, the physical extraction of crucible prills seems highly preferable (as was similarly concluded by Baron et al. (2014) for LI analysis of primary production slag and its embedded prills) and surely more cost-efficient. LA-ICP-MS analysis of crucible prills exposed in mounted sections might offer new opportunities as well.

\section{6 - Conclusion}

This paper has presented new chemical and lead isotope data for Egyptian copper alloys. Despite the current dearth of comparative data within (New Kingdom) Egypt, it provides important new ideas for the circulation of copper both within ancient Egypt and the eastern Mediterranean more widely, and illustrates the importance of incorporating chemical data in the interpretation of lead isotope ratios, embedded in broader archaeological arguments. Furthermore, it offers a detailed look at the provisioning of the large bronze workshops at PiRamesse, revealing the use of copper from multiple sources throughout the different contexts. It indicates, for the first time, the actual melting of Apliki oxhide ingot fragments in crucibles, and reinforces the suggested import of Arabah copper during the New Kingdom. Moreover, it implies the use of copper from Oman, as well as a major copper source of unknown origin, which may represent metal circulating in Egypt, used for recycling in Pi-Ramesse. This circulating copper, which matches other contemporary copper-based materials (Amarna, elRakham), may have consisted of copper smelted from Sinai/Eastern Desert as well as Omani ores, but cannot currently be fully characterised. Overall, this paper highlights the urgent necessity of continued research into Egyptian copper provisioning, for which a diachronic perspective of circulating copper is currently lacking. It is hoped, therefore, that the hypotheses raised in this paper, and their implications for understanding regional metal trade, will prompt further investigation of this subject. Finally, this paper has raised some methodological issues for LI analysis of crucibles. Though these may in some cases offer a proxy for LI ratios of metals molten in those crucibles, their interpretation is typically rather ambiguous. 


\section{Acknowledgements}

Results presented here are part of the first author's $\mathrm{PhD}$ research undertaken at the Institute of Archaeology at University College London, which was funded by an ESR fellowship from the European Union: Marie Curie ITN (FP7-PEOPLE-2010) NARNIA project (grant 265010). This funding has also covered analysis at the CEZA of 42 samples by MC-ICP-MS, QICP-MS ED-XRF and NAA. The remaining TIMS and XRF data (9 metal samples) was produced at the Oxford Isotrace laboratory in the context of the Pi-Ramesse project, currently based at UCLQatar.

We are very grateful to Edgar B. Pusch for his aid in the contextual interpretations of these crucibles and copper alloys, and for all the years of constructive collaboration. Thanks also go to Henning Franzmeier for providing background data and discussion. We also thank Zofia Stos-Gale for her help in acquiring the 1996 data presented in this paper. Comments from two anonymous reviewers have greatly helped to improve this manuscript. 


\section{Bibliography}

Abd El-Rahman, Y., Surour, A.A., El Manawi, A.H.W., Rifai, M., Abdel-Motelib, A., Ali, W.K., and El Dougdoug, A.M. (2013): Ancient mining and smelting activities in the Wadi Abu Gerida area, central Eastern Desert, Egypt: preliminary results, Archaeometry, 55, 1067-1087.

Abdel-Motelib, A., Bode, M., Hartmann, R., Hartung, U., Hauptmann, A., and Pfeiffer, K. (2012): Archaeometallurgical expeditions to the Sinai Peninsula and the Eastern Desert of Egypt (2006, 2008), Metalla (Bochum), 19, 3-59.

Abouzeid, A.-Z.M. and Khalid, A.-A.M. (2011): Mineral industry in Egypt - Part I: metallic mineral commodities, Natural Resources, 2, 35-53.

Adamson, D.A., Gasse, F., Street, F.A., and Williams, M.A.J. (1980): Late Quaternary history of the Nile, Nature, $288,50-55$.

Anwar, Y.M. (1964): Note on the occurrence of copper minerals at Ras Benas, Eastern Desert, Journal of the Geological Society of Egypt, 8, 89-94.

Baron, S., Tămaş, C.G., and Le Carlier, C. (2014): How mineralogy and geochemistry can improve the significance of $\mathrm{Pb}$ isotopes in metal provenance studies, Archaeometry, 56, 665-680.

Begemann, F., Hauptmann, A., Schmitt-Strecker, S., and Weisgerber, G. (2010): Lead isotope and chemical signature of copper from Oman and its occurrence in Mesopotamia and sites on the Arabian Gulf coast, Arabian Archaeology and Epigraphy, 21, 135-169.

Begemann, F., Kallas, K., Schmitt-Strecker, S., and Pernicka, E. (1999): Tracing ancient tin via isotope analyses, in A. Hauptmann, E. Pernicka, Th. Rehren, and Ü. Yalçin, eds., The Beginnings of Metallurgy, Bochum: Deutsches Bergbau-Museum, pp. 277-284.

Begemann, F., Schmitt-Strecker, S., and Pernicka, E. (2003): On the composition and provenance of metal finds from Beşiktepe (Troia), in G. A. Wagner, E. Pernicka, and H.-P. Uerpmann, eds., Troia and the Troad: Scientific Approaches, Berlin, Heidelberg, New York: Springer-Verlag, pp. 173-201

Beit-Arieh, I. (1985): Serabit el-Khadim: new metallurgical and chronological aspects, Levant, 17, 89-116.

Ben-Yosef, E., Levy, T.E., Higham, T., Najjar, M., and Tauxe, L. (2010): The beginning of Iron Age copper production in the southern Levant: new evidence from Khirbat al-Jariya, Faynan, Jordan, Antiquity, 84, 724-746.

Ben-Yosef, E., Shaar, R., Tauxe, L., and Ron, H. (2012): A new chronological framework for Iron Age copper production at Timna (Israel), Bulletin of the American Schools of Oriental Research, 367, 31-71.

Bokhari, F.Y. and Kramers, J.D. (1982): Lead isotope data from massive sulfide deposits in the Saudi Arabian shield, Economic Geology, 77, 1766-1769.

Brill, R.H., Barnes, I.L., and Adams, B. (1974): Lead isotopes in some ancient Egyptian objects, in A. Bishay, ed., Recent Advances in Science and Technology of Materials, Volume 3 (Proceedings of the Second Cairo Solid State Conference Held in Cairo, Egypt, April 21-26, 1973), New York: Plenum, pp. 9-27.

Budd, P., Pollard, A.M., Scaife, B., and Thomas, R.G. (1995): Oxhide ingots, recycling and the Mediterranean metals trade, Journal of Mediterranean Archaeology, 8, 1-32.

Chartier-Raymond, M., Gratien, B., Traunecker, C., and Vinçon, J.-M. (1994): Les site miniers pharaoniques du Sud-Sinai. Quelques notes et observations de terrain, Cahiers de Recherches de l'Institut de Papyrologie et d'Egyptologie de Lille, 16, 31-77. 
Constantinou, G. (1980): Metallogenesis associated with the Troodos ophiolite, in A. Panayiotou, ed., Ophiolites. Proceedings of the International Ophiolite Symposium, Cyprus, 1979, Nicosia: Cyprus Geological Survey Department, pp. 663-674.

Dixon, D.M. (2004): Pharaonic Egypt and the Red Sea arms trade, in P. Lunde and A. Porter, eds., Trade and Travel in the Red Sea Region: Proceedings of the Red Sea Project 1, Oxford: Archaeopress, BAR International Series 1269, Society for Arabian Studies Monographs No. 2, pp. 33-42.

Doe, B.R. and Rohrbough, R. (1977): Lead Isotope Databank: 3458 samples and analyses cited, United States Department of the Interior - Geological Survey open file report, 79-661.

Eccleston, M.A.J. and Kemp, B.J. (2008): Metalworking and crucibles, in B.J. Kemp and A.K. Stevens, eds., Busy Lives at Amarna: Excavations at Grid 12 in the Main City, London: Egypt Exploration Society, pp. 419-453.

El Gayar, E.-S. and Jones, M.P. (1989a): Old Kingdom copper smelting artifacts from Buhen in Upper Egypt, Historical Metallurgy, 23, 16-24.

El Gayar, E.-S. and Jones, M.P. (1989b): A possible source of copper ore fragments found at the Old Kingdom town of Buhen, Journal of Egyptian Archaeology, 75, 31-40.

El Goresy, A., Tera, F., Schlick-Nolte, B., and Pernicka, E. (1998): Chemistry and lead isotopic compositions of glass from a Ramesside workshop at Lisht and Egyptian lead ores: a test for a genetic link and for the source of glass, in C.J. Eyre, ed., Proceedings of the Seventh International Congress of Egyptologists. Cambridge, 3-9 September 1995, Orientalia Lovaniensia Analecta 82, Leuven: Peeters, pp. 471-481.

Ellam, R.M., Hawkesworth, C.J., and McDermott, F. (1990): Pb isotope data from late Proterozoic subductionrelated rocks: implications for crust-mantle evolution, Chemical Geology, 83, 165-181.

Ellingham, H.J.T. (1944): Reducibility of oxides and sulphides in metallurgical processes, Journal of the Society of Chemical Industry, 5, 125-133.

Fattovich, R. (2012): Egypt's trade with Punt: new discoveries on the Red Sea coast, British Museum Studies in Ancient Egypt and Sudan, 18, 1-59.

Fleming, S.J. (1982): Lead isotope analyses of Late Period Egyptian bronzes, MASCA Journal, 2, 65-69.

Foucault, A. and Stanley, D.J. (1989): Late Quaternary paleoclimatic oscillations in East Africa recorded by heavy minerals in the Nile delta, Nature, 339, 44-46.

Freestone, I.C., Kunicki-Goldfinger, J., Gilderale-Scott, H., and Ayers, T. (2010): Multi-disciplinary investigation of the windows of John Thornton, focusing on the Great East Window of York Minster, in M.B. Shepard, L. Pilosi, and S. Strobl, eds., The Art of Collaboration: Stained Glass Conservation in the Twenty-first Century, Turnhout: Harvey Millar, pp. 151-158.

Freestone, I.C., Price, J., and Cartwright, C. (2009a): The batch: its recognition and significance, Annales du 17eme Congrès de l'Association Internationale pour l'Histoire du Verre, pp. 130-135.

Freestone, I.C., Yegingil, Z., and Arik, R. (2009): Scientific analysis of glazed tile from the Seljuq palace of Kubad-Abad, Lake Beysehir, Turkey, in B. McCarthy, E.S. Chase, and L. Allis, eds., Scientific Research on Historic Asian Artefacts: Proceedings of the Fourth Forbes Symposium at the Freer Gallery of Art, London and Washington, DC: Archetype in association with the Freer Gallery of Art, pp. 3-8.

Gale, N.H. (1999): Lead isotope characterization of the ore deposits of Cyprus and Sardinia and its application to the discovery of the sources of copper for Late Bronze Age oxhide ingots, in S.M.M. Young, A.M. Pollard, P. Budd, and R.A. Ixer, eds., Metals in Antiquity, BAR S792, Oxford: Archaeopress, pp. 110-121. 
Gale, N.H. (2005): Die Kupferbarren von Uluburun. Teil 2: Bleiisotopenanalysen von Bohrkernen aus den Barren, in Ü. Yalçin, C. Pulak, and R. Slotta, eds., Das Schiff von Uluburun. Welthandel vor 3000 Jahren, Bochum: Deutsches Bergbau-Museum, pp. 141-148.

Gale, N.H. (2011): Copper oxhide ingots and lead isotope provenancing, in P.P. Betancourt and S.C. Ferrence, eds., Metallurgy: Understanding How, Learning Why. Studies in Honor of James D. Muhly, Philadelphia, PA: INSTAP Academic Press, pp. 213-220.

Gale, N.H., Bachmann, H.-G., Rothenberg, B., Stos-Gale, Z.A., and Tylecote, R.F. (1990): The adventitious production of iron in the smelting of copper, in B. Rothenberg, ed., The Ancient Metallurgy of Copper: Archaeology-Experiment-Theory. (Researches in the Arabah 1959-84; v. 2), London: The Institute for ArchaeoMetallurgical Studies, pp. 182-191.

Gale, N.H., Kayafa, M., and Stos-Gale, Z.A. (2007): Further evidence for Bronze Age production of copper from ores in the Lavrion district, Attica, Greece, in Archaeometallurgy in Europe 2007. Selected papers of the 2nd International Conference 17.-21. June 2007 in Aquileia, Milan: Associazione Italiana di Metallurgia, pp. 158176.

Gale, N.H. and Stos-Gale, Z.A. (2012): The role of the Apliki mine region in the post c. 1400 BC copper production and trade networks in Cyprus and the wider Mediterranean, in V. Kassianidou and G. Papasavvas, eds., Eastern Mediterranean Metallurgy and Metalwork in the Second Millennium BC - A Conference in Honour of James D. Muhly, Nicosia, 10th-11th October 2009, Oxford: Oxbow Books, pp. 70-82.

Gale, N.H., Stos-Gale, Z.A., Maliotis, G., and Annetts, N. (1997): Lead isotope data from the Isotrace Laboratory, Oxford: Archaeometry data base 4, ores from Cyprus, Archaeometry, 39, 237-246.

Garenne-Marot, L. (1984): Le cuivre en Egypte pharaonique: sources et métallurgie, Paléorient, 10, 97-126.

Garson, M.S. (1977): Younger granites of Egypt and associated mineralization, Transactions of the Institution of Mining and Metallurgy, 86, 161.

Garzanti, E., Andò, S., Vezzoli, G., Abdel Megid, A.A., and El Kammar, A. (2006): Petrology of Nile River sands (Ethiopia and Sudan): sediment budgets and erosion patterns, Earth and Planetary Science Letters, 252, $327-341$.

Galili, E., Gale, N.H., and Rosen, B. (2013): A Late Bronze Age shipwreck with a metal cargo from Hishuley Carmel, Israel, The International Journal of Nautical Archaeology, 42, 2- 23.

Gestoso Singer, G. (2015): Small ingots and scrap metal in the eastern Mediterranean during the Late Bronze Age, in J. Mynárová, P. Onderka, and P. Pavúk, eds., There and Back Again - the Crossroads II, Charles University in Prague, Faculty of Arts, pp. 85-127.

Hamza, M. (1930): Excavations of the Department of Antiquities at Qantir (Faqus District), Annales du Service des Antiquités de l'Egypte, 30, 31-68.

Hauptmann, A. (2007): The Archaeometallurgy of Copper - Evidence from Faynan, Jordan, Springer.

Hauptmann, A., Begemann, F., Heitkemper, E., Pernicka, E., and Schmitt-Strecker, S. (1992): Early copper produced at Feinan, Wadi Araba, Jordan: the composition of ores and copper, Archeomaterials, 6, 1-33.

Hauptmann, A., Maddin, R., and Prange, M. (2002): On the structure and composition of copper and tin ingots excavated from the shipwreck of Uluburun, Bulletin of the American Schools of Oriental Research, 328, 1-30.

Hauptmann, A., Schmitt-Strecker, S., Levy, T.E., and Begemann, F. (2015): On Early Bronze Age copper bar ingots from the southern Levant, Bulletin of the American Schools of Oriental Research, 373, 1-24. 
Hikade, T. (1998): Economic aspects of the New Kingdom: the expeditions to the copper mines of the Sinai, Bulletin of the Australian Centre for Egyptology, 9, 43-52.

Hikade, T. (2006): Expeditions to the Wadi Hammamat during the New Kingdom, Journal of Egyptian Archaeology, 92, 153-168.

Hikade, T. (2007): Crossing the frontier into the desert: Egyptian expeditions to the Sinai Peninsula, Ancient West and East, 6, 1-22.

Hussein, A.A.A. and El Sharkawi, M.A. (1990): Mineral deposits, in R. Said, ed., The Geology of Egypt, Rotterdam: Balkema, pp. 511-566.

Höppner, B., Bartelheim, M., Huijsmans, M., Krauss, R., Martinek, K.-P., Pernicka, E., and Schwab, R. (2005): Prehistoric copper production in the Inn valley, Austria, and the earliest copper in central Europe, Archaeometry, 47, 293-315.

Jaksch, H., Seipel, W., Weiner, K.L., and El Goresy, A. (1983): Egyptian blue - cuprorivaite: a window to ancient Egyptian technology, Naturwissenschaften, 70, 525-535.

Kassianidou, V. (2009): Oxhide ingots in Cyprus, in F. Lo Schiavo, J.D. Muhly, R. Maddin, and A. Giumlia-Mair, eds., Oxhide Ingots in the Central Mediterranean, A.G. Leventis Foundation and CNR Instituto di Studi sulle Civiltà dell'Egeo e del Vicino Oriente, pp. 41-81.

Kassianidou, V. (2013): The production and trade of Cypriot copper in the Late Bronze Age. An analysis of the evidence, Pasiphae, 7, 133-146.

Klemm, R. and Klemm, D.D. (1994): Chronologischer Abriß der antiken Goldgewinnung in der Ostwüste Ägyptens, Mitteilungen des Deutschen Archäologischen Instituts Abteilung Kairo, 50, 189-222.

Klemm, R. and Klemm, D.D. (2013): Gold and Gold Mining in Ancient Egypt and Nubia. Geoarchaeology of the Ancient Gold Mining Sites in the Egyptian and Sudanese Eastern Deserts, Berlin: Springer.

Krom, M.D., Stanley, D.J., Cliff, R.A., and Woodward, J.C. (2002): Nile River sediment fluctuations over the past $7000 \mathrm{yr}$ and their key role in sapropel development, Geology, 30, 71-74.

Langmuir, C.H., Vocke, R.D.J., Hanson, G.N., and Hart, S.R. (1978): A general mixing equation with applications to Icelandic basalts, Earth and Planetary Science Letters, 37, 380-392.

Lehner, J.W., Yener, K.A., and Burton, J. (2009): Lead isotope analysis and chemical characterization of metallic residues of an Early Bronze Age crucible from Göltepe using ICP-MS, Turkiye Bilimler Akademisi Arkeoloji Dergisi (TUBA-AR). Turkish Academy of Sciences Journal of Archaeology, 12, 165-174.

Leusch, V., Armbruster, B., Pernicka, E., Slavčev, V. (2015): On the Invention of Gold Metallurgy: The Gold Objects from the Varna I Cemetery (Bulgaria)—Technological Consequence and Inventive Creativity. Cambridge Archaeological Journal 25:1, 353-376.

Levy, T.E., Ben-Yosef, E., and Najjar, M. (2012): New perspectives on Iron Age copper production and society in the Faynan Region, Jordan, in V. Kassianidou and G. Papasavvas, eds., Eastern Mediterranean Metallurgy and Metalwork in the Second Millennium BC - A Conference in Honour of James D. Muhly, Nicosia, 10th-11th October 2009, Oxford: Oxbow Books, pp. 197-214.

Ling, J., Stos-Gale, Z.A., Grandin, L., Billström, K., Hjärthner-Holdar, E., and Persson, P.-O. (2014): Moving metals II: provenancing Scandinavian Bronze Age artefacts by lead isotope and elemental analyses, Journal of Archaeological Science, 41, 106-132. 
Liu, S., Rehren, Th., Pernicka, E., and Hausleiter, A. (2015): Copper processing in the oases of northwest Arabia: technology, alloys and provenance, Journal of Archaeological Science, 53, 492-503.

Lo Schiavo, F., Sorge, E., Cucuzza, N., Gale, N.H., and Stos-Gale, Z.A. (2013): An oxhide ingot fragment from Piazzale dei Sacelli, Ayia Triada (Crete) to the National Archaeological Museum, Florence, in G. Graziadio, R. Guglielmino, V. Lenuzza, and S. Vitale, eds., Studies in Mediterranean Archaeology for Mario Benzi, BAR International Series 2460, Oxford: Archaeopress, pp. 49-60.

Lucas, A. (1962): Ancient Egyptian Materials and Industries, London: Edward Arnold.

Lutz, J., Pernicka, E. (1996): Energy dispersive X-ray fluorescence analysis of ancient copper alloys: empirical values for precision and accuracy, Archaeometry, 38, 313-323.

Martinón-Torres, M., Li, X.J., Bevan, A., Xia, Y., Zhao, K. and Rehren, Th. (2014): Forty thousand arms for a single emperor: from chemical data to the labor organization behind the bronze arrows of the terracotta army, Journal of Archaeological Method and Theory, 21, 534-562.

Martinón-Torres, M. and Uribe-Villegas, M.A. (2015): The prehistoric individual, connoisseurship and archaeological science: the Muisca goldwork of Colombia, Journal of Archaeological Science, 63, 136-155.

Meeks, D. (2003): Locating Punt, in D. O’Connor and S. Quirke, eds., Mysterious Lands, London: UCL Press, pp. 53-80.

Merkel, J.F. (1990): Experimental reconstruction of Bronze Age copper smelting based on archaeological evidence from Timna, in B. Rothenberg, ed., The Ancient Metallurgy of Copper: Archaeology-ExperimentTheory. (Researches in the Arabah 1959-84; v. 2), London: The Institute for Archaeo-Metallurgical Studies, pp. $78-122$.

Molofsky, L.J., Killick, D., Ducea, M.N., Macovei, M., Chesley, J.T., Ruiz, J., Thibodeau, A., and Popescu, G.C. (2014): A novel approach to lead isotope provenance studies of tin and bronze: applications to South African, Botswanan and Romanian artifacts, Journal of Archaeological Science, 50, 440-450.

Muhly, J.D. (2003): Trade in metals in the Late Bronze Age and the Iron Age, in N. Chr. Stampolidis and V. Karageorghis, eds., Sea Routes... Interconnections in the Mediterranean 16th - 6th c. BC. Proceedings of the International Symposium held at Rethymnon, Crete, September 29th - October 2nd, 2002, Athens: The University of Crete and the A.G. Leventis Foundation, pp. 141-150.

Muhly, J.D. (2009): Oxhide ingots in the Aegean and Egypt, in F. Lo Schiavo, J.D. Muhly, R. Maddin, and A. Giumlia-Mair, eds., Oxhide Ingots in the Central Mediterranean, Rome: A.G. Leventis Foundation. CNR Instituto di Studi sulle Civiltà dell'Egeo e del Vicino Oriente, pp. 17-39.

Niederschlag, E., Pernicka, E., Seifert, Th., and Bartelheim, M. (2003): The determination of lead isotope ratios by multiple collector ICP-MS: a case study of Early Bronze Age artefacts and their possible relation with ore deposits of the Erzgebirge, Archaeometry, 45, 61-100.

Ogden, J. (2000): Metals, in P.T. Nicholson and I. Shaw, eds., Ancient Egyptian Materials and Technology, Cambridge: Cambridge University Press, pp. 148-176.

Pernicka, E. (1984): Instrumentelle Multi-Elementanalyse archäologischer Kupfer- und Bronzeartefakte: Ein Methodenvergleich. Jahrbuch des Römisch-Germanischen Zentralmuseums, 31, 517-531.

Pernicka, E. (2014): Provenance determination of archaeological metal objects, in B.W. Roberts and C.P. Thornton, eds., Archaeometallurgy in Global Perspective, Springer, pp. 239-268.

Pernicka, E., Begemann, F., Schmitt-Strecker, S., and Grimanis, A.P. (1990): On the composition and provenance of metal artefacts from Poliochni on Lemnos, Oxford Journal of Archaeology, 9, 263-298. 
Pernicka, E., Begemann, F., Schmitt-Strecker, S., and Wagner, G.A. (1993): Eneolithic and Early Bronze Age copper artefacts from the Balkans and their relation to Serbian copper ores, Praehistorische Zeitschrift, 68, 1-54.

Pernicka, E., Lutz, J., and Stöllner, Th. (2016): Bronze Age copper produced at Mitterberg, Austria, and its distribution, Archaeologia Austriaca, 100 (in print).

Petschel, S. (2011): Den Dolch betreffend. Typologie der Stichwaffen in Ägypten von der prädynastischen Zeit bis zur 3. Zwischenzeit, Wiesbaden: Harrassowitz Verlag.

Philip, G., Clogg, P.W., and Dungworth, D. (2003): Copper metallurgy in the Jordan valley from the third to the first millennia BC: chemical, metallographic and lead isotope analyses of artefacts from Pella, Levant, 35, 71100 .

Pinarelli, L. (2004): Lead isotope characterisation of copper ingots from Sardinia (Italy): inferences on their origins, Bulletin of the Geological Society of Greece, 36, 1173-1180.

Prell, S. (2011): Einblicke in die Werkstätten der Residenz - Die Stein- und Metallwerkzeuge des Grabungsplatzes $Q$ I, Forschungen in der Ramses-Stadt Band 8, Hildesheim: Gerstenberg Verlag.

Primas, M., and Pernicka, E. (1998): Der Depotfund von Oberwilflingen; neue Ergebnisse zur Zirkulation von Metallbarren, Germania, 76, 25-62.

Pusch, E. B. (1990): Metallverarbeitende Werkstätten der frühen Ramessidenzeit in Qantir-Piramesse/Nord - Ein Zwischenbericht, Ägypten und Levante, 1, 75-113.

Pusch, E.B. (1994): Divergierende Verfahren der Metallverarbeitung in Theben und Qantir? Bemerkungen zur Konstruktion und Technik, Ägypten und Levante, 4, 145-170.

Pusch, E.B. (1999): Goldschmiedewerkstatt oder vergoldeter Fußboden?, Ägypten und Levante, 9, $121-133$.

Pusch, E.B. (2000): Doors - statues - musical instruments? Large scale bronze production and casting at the Delta residence of the Ramessides, Egypt, in R. Eichmann, E. Hickmann, and I. Laufs, eds., Musikarchäologie früher Metallzeiten; Vorträge des 1. Symposiums der International Study Group on Music Archaeology im Kloster Michaelstein, 18.-24. März 1998, Studien zur Musikarchäologie 2; Orient-Archäologie 7, Leidorf, pp. $219-232$.

Pusch, E.B. and Herold, A. (1999): Qantir/Pi-Ramesses, in K. Bard, ed., Encyclopedia of the Archaeology of Ancient Egypt, London: Routledge, pp. 647-649.

Rademakers, F.W. (2015): Into the Crucible. Methodological Approaches to Reconstructing Crucible Metallurgy, from New Kingdom Egypt to Late Roman Thrace, Unpublished PhD Thesis, University College London, URI: http://discovery.ucl.ac.uk/id/eprint/1469615

Rademakers, F.W. and Rehren, Th. (2016): Seeing the forest for the trees: Assessing technological variability in ancient metallurgical crucible assemblages, Journal of Archaeological Science: Reports, 7, 588-596.

Rademakers, F.W., Rehren, Th., and Pusch, E.B. (in press): Bronze production in Pi-Ramesse: alloying technology and material use, in E. Ben-Yosef and Y. Goren, eds., Mining for Copper: Essays in Honor of Professor Beno Rothenberg, Tel Aviv: Institute of Archaeology of Tel Aviv University.

Rehren, Th. and Pernicka, E. (2014): First data on the nature and origin of the metalwork from Tell el-Farkha, in A. Maczynska, ed., The Nile Delta as a Centre of Cultural Interactions between Upper Egypt and the Southern Levant in the 4th Millennium BC, Studies in African Archaeology 13, Poznan, pp. 237-252.

Rehren, Th. and Pusch, E.B. (2012): Alloying and resource management in New Kingdom Egypt: the bronze industry at Qantir - Pi-Ramesse and its relationship to Egyptian copper sources, in V. Kassianidou and G. 
Papasavvas, eds., Eastern Mediterranean Metallurgy and Metalwork in the Second Millennium BC - A Conference in Honour of James D. Muhly, Nicosia, 10th-11th October 2009, Oxford: Oxbow Books, pp. 215-221.

Rehren, Th., Pusch, E.B., and Herold, A. (1998): Glass coloring works within a copper-centered industrial complex in Late Bronze Age Egypt, in P. McCray and W.D. Kingery, eds., The Prehistory and History of Glassmaking Technology, Ceramics and Civilization Vol. 8, The American Ceramic Society, pp. 227-250.

Rehren, Th., Pusch, E.B., and Herold, A. (2001): Qantir-Piramesses and the organisation of the Egyptian glass industry, in A. Shortland, ed., The Social Context of Technological Change. Egypt and the Near East, 1650-1550 $B C$, Oxford: Oxbow Books, pp. 223-238.

Rothenberg, B. (1980): Die Archaeologie des Verhüttungslagers Site 30, in H.G. Conrad and B. Rothenberg, eds., Antikes Kupfer im Timna-Tal: 4000 Jahre Bergbau und Verhüttung in der Arabah (Israel), Bochum: Vereinigung der Freunde von Kunst und Kultur im Bergbau, pp. 187-214.

Rothenberg, B. (1987): Pharaonic copper mines in South Sinai, Institute of Archaeo-Metallurgical Studies Newsletter, 10-11, 1-7.

Rothenberg, B. (1988): The Egyptian Mining Temple at Timna, London: The Institute for Archaeo-Metallurgical Studies.

Rothenberg, B., ed. (1990): The Ancient Metallurgy of Copper: Archaeology-Experiment-Theory. (Researches in the Arabah 1959-84; v. 2), London: The Institute for Archaeo-Metallurgical Studies.

Said, R. (1981): The Geological Evolution of the River Nile, New York: Springer.

Seeliger, T.C., Pernicka, E., Wagner, G.A., Begemann, F., Schmitt-Strecker, S., Eibner, C., Öztunalı, Ö., and Baranyi, I. (1985), Archäometallurgische Untersuchungen in Nord- und Ostanatolien, Jahrbuch des RömischGermanischen Zentralmuseums Mainz, 32, 597-659.

Segal, I., Halicz, L., and Cohen, R. (1999): A study of ingots and metallurgical remains from `Ein Ziq and Be`er Resisim, Central Negev, Israel, in S.M.M. Young, A.M. Pollard, P. Budd, and R.A. Ixer, eds., Metals in Antiquity, BAR S792, Oxford: Archaeopress, pp. 179-186.

Shaw, I. (1994): Pharaonic quarrying and mining: settlement and procurement in Egypt's marginal regions, Antiquity, 68, 108-119.

Shaw, I. (1998): Exploiting the desert frontier. The logistics and politics of ancient Egyptian mining expeditions, in A.B. Knapp, V.C. Pigott, and E.W. Herbert, eds., Social Approaches to an Industrial Past, London and New York: Routledge, pp. 242-258.

Shortland, A.J. (2006): Application of lead isotope analysis to a wide range of Late Bronze Age Egyptian materials, Archaeometry, 48, 657-669.

Stacey, J.S., Doe, B.R., Roberts, R.J., Delevaux, M.H., and Gramlich, J.W. (1980): A lead isotope study of mineralization in the Saudi Arabian Shield, Contributions to Mineralogy and Petrology, 74, 175-188.

Stanley, D.J., Sheng, H., and Pan, Y. (1988): Heavy minerals and provenance of Late Quaternary sands, eastern Nile Delta, Journal of African Earth Sciences, 7, 735-741.

Stos, Z.A. (2009): Across the wine dark seas... sailor tinkers and royal cargoes in the Late Bronze Age eastern Mediterranean, in A.J. Shortland, I.C. Freestone, and Th. Rehren, eds., From Mine to Microscope. Advances in the Study of Ancient Technology, Oxford: Oxbow Books, pp. 163-180. 
Stos-Fertner, Z.A. and Gale, N.H. (1979): Chemical and lead isotope analysis of ancient Egyptian gold, silver and lead, in I. Scollar, ed., Proceedings of the 18th International Symposium on Archaeometry and Archaeological Prospection, Bonn, 14-17 March 1978, Archaeo-Physika Band 10, Köln: Rheinland-Verlag GmbH, pp. $299-314$.

Stos-Gale, Z.A. (2011): "Biscuits with ears": a search for the origin of the earliest oxhide ingots, in P.P. Betancourt and S.C. Ferrence, eds., Metallurgy: Understanding How, Learning Why. Studies in Honor of James D. Muhly, Philadelphia, PA: INSTAP Academic Press, pp. 221-229.

Stos-Gale, Z.A. and Gale, N.H. (1981): Sources of galena, lead and silver in predynastic Egypt, Revue d'Archéometrie, 1 (Actes du XXe symposium international d'archéométrie, Paris, 26-29 mars 1980 Volume III), 285-296.

Stos-Gale, Z.A. and Gale, N.H. (2009): Metal provenancing using isotopes and the Oxford archaeological lead isotope database (OXALID), Archaeological and Anthropological Sciences, 1, 195-213.

Stos-Gale, Z.A., Gale, N.H., and Houghton, J. (1995a): The origins of Egyptian copper: lead-isotope analysis of metals from el-Amarna, in V.W. Davies and L. Schofield, eds., Egypt, the Aegean and the Levant: Interconnections in the Second Millennium BC, London: British Museum Press, pp. 127-135.

Stos-Gale, Z.A., Gale, N.H., Houghton, J., and Speakman, R. (1995b): Lead isotope data from the Isotrace Laboratory, Oxford: Archaeometry data base 1, ores from the Western Mediterranean, Archaeometry, 37, 407415 .

Stos-Gale, Z.A., Maliotis, G., Gale, N.H., and Annetts, N. (1997): Lead isotope characteristics of the Cyprus copper ore deposits applied to provenance studies of copper oxhide ingots, Archaeometry, 39, 83-123.

Thomas, S. (2000): Aspects of Technology and Trade in Egypt and the Eastern Mediterranean during the Late Bronze Age, Unpublished PhD thesis, University of Liverpool.

Wagner, G.A. and Öztunali, Ö. (2000): Prehistoric copper sources in Turkey, in Ü. Yalcin, ed., Anatolian Metal I, Der Anschnitt, Beiheft 13, Deutsches Bergbau-Museum, Bochum, pp. 31-66.

Wagner, G.A., Begemann, F., Eibner, C., Lutz, J., Öztunali, Ö., Pernicka, E., and Schmitt-Strecker, S. (1989): Archäometallurgische Untersuchungen an Rohstoffquellen des frühen Kupfers in Ostanatolien, Jahrbuch des Römisch-Germanischen Zentralmuseums Mainz, 36, 637-686.

Wagner, G.A., Pernicka, E., Seeliger, T.C., Lorenz, I.B., Begemann, F., Schmitt-Strecker, S., Eibner, C., and Öztunali, Ö. (1986): Geochemische und isotopische Charakteristika früher Rohstoffquellen für Kupfer, Blei, Silber und Gold in der Türkei, Jahrbuch des Römisch-Germanischen Zentralmuseums Mainz, 33, 723-730.

Wagner, G.A., Pernicka, E., Seeliger, T.C., Öztunali, Baranyi, I., Begemann, F., and Schmitt-Strecker, S. (1985): Geologische Untersuchungen zur frühen Metallurgie in NW-Anatolien, Bulletin of the Mineral and Exploration Institute of Turkey, 101/102, 45-81.

Weeks, L., Keall, E., Pashley, V., Evans, J., and Stock, S. (2009): Lead isotope analyses of Bronze Age copperbase artefacts from al-Midamman, Yemen: towards the identification of an indigenous metal production and exchange system in the southern Red Sea region, Archaeometry, 51, 576-597.

Willet, F. and Sayre, E.V. (2006): Lead isotope in West African copper alloys, Journal of African Archaeology, 4, 55-90.

Yahalom-Mack, N., Galili, E., Segal, I., Eliyahu-Behar, A., Boaretto, E., Shilstein, S., and Finkelstein, I. (2014): New insights into Levantine copper trade: analysis of ingots from the Bronze and Iron Ages in Israel, Journal of Archaeological Science, 45, 159-177. 
Yener, K.A., Sayre, E.V., Joel, E.C., Özbal, H., Barnes, I.L., and Brill, R.H. (1991): Stable lead isotope studies of Central Taurus ore sources and related artifacts from eastern Mediterranean Chalcolithic and Bronze Age sites, Journal of Archaeological Science, 18, 541-577. 